\title{
Milk Proteins' Polymorphism in Various Species of Animals Associated with Milk Production Utility
}

\author{
Joanna Barłowska, Anna Wolanciuk, Zygmunt Litwińczuk and Jolanta Król
}

Additional information is available at the end of the chapter

http://dx.doi.org/10.5772/75168

\section{Introduction}

In the recent years a significant progress has occurred in the understanding of many of the complex processes in cells of the body at a molecular level. To clarify the basis of this phenomenon the development in the field of molecular biology was a great contribution. This area has provided many hitherto unknown tools that enabled the understanding of fundamental life processes at a basic level. The utilization of the achievements of biological and zootechnical sciences led to a significant increase in animal productivity.

The first research studies concerning the detection of genetic diversity among farm animals were based on morphological, chromosomal and biochemical markers and therefore, they are not free of defects. Most of the morphological markers are limited by gender or age and are influenced by the environment. The biochemical markers, however, contribute to low levels of polymorphism (Boichard et al., 2003; Naqvi, 2007). Currently a key role in animal genetics is connected with molecular markers. Molecular markers are specific pieces of DNA that can be identified within the genome and are inherited according to Mendel's laws (Teneva \& Petrović, 2010). They can be successfully utilized to detect and track the inheritance mechanisms of polymorphic traits that contribute to genetic diversity (Khatkar et al., 2004). Molecular markers which enable the detection of genetic variants at DNA sequence level are devoid of these limitations typical for morphological, chromosomal and protein markers. They also have unique properties that make them more useful than other markers. They are ubiquitous throughout the genome, often multi-allelic, giving an average heterozygosity of more than $70 \%$. What is more, molecular markers are not influenced by environment and usually do not have pleiotropic effect on quantitative traits loci (QTL) (Teneva, 2009). 
Up to date, numerous techniques of studying DNA variations at the molecular level are known. The most famous include RFLP (restriction fragment length polymorphism), SNP (single nucleotide polymorphism) and STR (microsatellite DNA polymorphism) (Beuzen et al., 2000; Teneva \& Petrović, 2010).

\section{RFLP (restriction fragment length polymorphism)}

Restriction fragment length polymorphism (RFLP) is associated with the occurrence of differences in nucleotide sequences in the gene. It is a result of point mutations, which may manifest themselves phenotypically. They appear through the use of restriction enzymes that recognize sequences specific to their nucleotide. The mutations result in the creation of new places that are identified by restriction enzymes that cut DNA into fragments of various lengths. This technique consists of amplification of specific parts of the genome and the amplicon is digested by one or more restriction enzymes. The obtained DNA fragments are distributed on an agarose gel and, depending on their size, migrate at different speed rates. Smaller fragments tend to move faster in the comparison to larger ones (Beuzen et al., 2000; Bogdzińska, 2011; Marle-Köster \& Nel, 2003).

\section{SNP (single nucleotide polymorphism)}

The system enables detection of single nucleotide polymorphism within the examined DNA sequences. It is based on the amplification of specific parts of the genome in the PCR reaction and sequencing of the product obtained. A comparison between electrophoresis images of amplification products is conducted, which allows determining whether a mutation in a given region had occurred. Point mutation leads to the formation of a polymorphic SNP if each of the alleles appear in the population with the frequency not lesser than $1 \%$. What is more, these markers are present in both coding and non-coding parts of the genome (Stoneking, 2001). SNP polymorphism is usually associated with the presence of only two alleles in the gene pool of the population (Beuzen et al., 2000). On the one hand, a great advantage of this polymorphism is its university in the genome of different species and highly efficient identification of polymorphism within the tested sequence while on the other hand, the high cost of the analysis makes it a disadvantage. The high density of SNP markers in the genome leads to their extensive utilization in the genetic analysis (Charon \& Świtoński, 2000).

\section{Microsatellite DNA}

Genetic diversity may be also determined by utilization of microsatellite sequences. This group of markers is polymorphic in more than $90 \%$ of the cases. Microsatellites are also known as simple sequence repeats (SSR) or short tandem repeats (STR). These repeats consist of several nucleotides (1-6) sequences also referred to as motifs. They are repeated from 20 to 50 times and their lengths range from 60 to 300 bp (Ellegren, 2004; Liu \& Cordes, 2004). They occur mainly in non-coding regions of the genes, thus they can be also identified in flanking sequences or more rarely in coding sequences. What is more, they are characterized by uniform dispersion at 6000 to 10000 bp (Li et al., 2004; Liu et al., 2001). The function of microsatellites is not yet fully understood (Li et al., 2002). Probably through the 
dispersion across the genome they have an impact on increasing or decreasing the expression of genes (Pisarchik \& Kartel, 2000). Features of microsatellites like high level of polymorphism, high frequency of occurrence, ease of identification and uniform distribution across the genome contributed to their common usage. They are used in the estimation of the genetic variability of animals, in the research on the control of origin, to characterize the structure and degree of inbreeding of the population and also to identify the genes of quantitative traits (QTL). What is more, they are used to conduct the selection based on genetic markers (MAS- Marker Assisted Selection) (Citek et al., 2006).

In the evaluation procedure of animals breeding value the knowledge of genome organization and polymorphism is increasingly utilized due to the fact of vast and easy access to many molecular technics. What is more, many mutations directly affecting the phenotype were recognized. On the other hand, thousands of anonymous genetic markers, because of their potential linkage with novel mutations of large scale of activity, may be utilized for estimation of the breeding values and selection based on genetic markers (MAS).

\section{Location of genes and the frequency of alleles conditioning the synthesis of selected milk proteins in most species of animals used for milk productivity}

The major milk proteins include casein: $\alpha \mathrm{s}_{1-}, \alpha \mathrm{s}_{2},-\beta-, \kappa-$ and two whey proteins: $\alpha-$ lactalbumin and $\beta$-lactoglobulin. These fractions, in most species, are polymorphic.

\subsection{Cattle}

Polymorphism of milk proteins has been widely explored in the case of cattle. Cattle casein loci is located on chromosome 6 (6/BTA 6q31-33) and occupies a total DNA fragment of 200 kb. Genes are arranged in order: CSN1S1, CSN2, CSN1S2, CSN3 and encode, respectively: $\alpha$ s1-casein, $\alpha_{\mathrm{s} 2}$-casein, $\beta$-casein and $\kappa$-casein. These genes are closely linked and form a cluster (Bai et al., 2008; Caroli et al., 2009).

$\alpha$ s1-casein is a fraction which forms up to $40 \%$ of bovine caseins in milk. It consists of one major and one minor component. Both of these proteins are composed of a single polypeptide chain of the same amino acid sequence. The reference protein for this family is $\alpha$ s1-CN B-8P, a single chain protein with no cysteine residues. It consists of 199 amino acids residues: Asp7, Asns, Thr5, Ser8, Ser P8, Glu25, Gln14, Prol7, Gly9, Ala9, Val11, Met5, Ile11, Leu17, Tyrio, Phes, Lysı, His5, Trp2, and Arg6 with a molecular mass of 23.615 (Mercier et al., 1971). So far 8 alleles were identified within the $\alpha$ s1-casein: A, B, C, D, E, F, G and H (Farrell et al., 2004). The most frequent, however, are alleles $B$ and $C$ found both in dairy and beef cattle (Litwińczuk et al., 2006). For European cattle breeds allele B is the most common - it exceeds the frequency of 0.9 (Kučerova et al., 2006; Luhken et al., 2009). Allele B at the 192 position of the polypeptide chain encodes glutathione, whereas the allele $C$ encodes glycine. Variant $A$ occurs sporadically. Alleles C, D and E were created due to the mutation of allele B. Table 1 shows the frequencies of as1-casein alleles in various breeds of cattle. 


\begin{tabular}{|c|c|c|}
\hline Cattle breed & $\begin{array}{c}\text { Allelic frequencies of } \\
\alpha \mathrm{s}_{1} \text {-casein }\end{array}$ & References \\
\hline Holstein-Friesian & $\begin{array}{l}\mathrm{B}=0.981 \\
\mathrm{C}=0.019\end{array}$ & \multirow{2}{*}{ Çardak, 2005} \\
\hline Simmentaler & $\begin{array}{l}B=0.932 \\
C=0.068\end{array}$ & \\
\hline Reggiana & $\begin{array}{l}B=0.750 \\
C=0.250\end{array}$ & Caroli et al., 2004 \\
\hline Uruguayan Creole & $\begin{array}{l}B=0.8654 \\
C=0.1346\end{array}$ & Rincón et al., 2006 \\
\hline Polish Red & $\begin{array}{l}\mathrm{B}=0.928 \\
\mathrm{C}=0.042 \\
\mathrm{D}=0.030\end{array}$ & \multirow{3}{*}{ Erhardt et al., 1998} \\
\hline Red Danish Dairy Cattle & $\begin{array}{l}A=0.003 \\
B=0.994 \\
C=0.003\end{array}$ & \\
\hline German Red & $\begin{array}{l}\mathrm{B}=0.975 \\
\mathrm{C}=0.025\end{array}$ & \\
\hline Czech Fleckvieh & $\begin{array}{l}\mathrm{B}=0.893 \\
\mathrm{C}=0.107\end{array}$ & Kučerova et al., 2006 \\
\hline $\begin{array}{l}\text { Hereford and crossbreeding } F_{1} \\
\text { and } R_{1} \text { (Black and White } x \\
\text { Hereford) }\end{array}$ & $\begin{array}{l}A=0.025 \\
B=0.710 \\
C=0.136 \\
D=0.130\end{array}$ & \multirow{3}{*}{ Litwińczuk \& Król, 2002} \\
\hline $\begin{array}{l}\text { Limousine and crossbreeding } F_{1} \\
\text { and } R_{1} \text { (Black and White } x \\
\text { Limousine) }\end{array}$ & $\begin{array}{l}A=0.020 \\
B=0.617 \\
C=0.214 \\
D=0.148\end{array}$ & \\
\hline Simmentaler & $\begin{array}{l}B=0.750 \\
C=0.250\end{array}$ & \\
\hline Estonian Native & $\begin{array}{l}B=0.915 \\
C=0.085\end{array}$ & \multirow{3}{*}{ Jõuru et al., 2007} \\
\hline Western Finncattle & $\begin{array}{l}\mathrm{B}=0.939 \\
\mathrm{C}=0.061\end{array}$ & \\
\hline Danish Jersey & $\begin{array}{l}B=0.781 \\
C=0.219\end{array}$ & \\
\hline $\begin{array}{l}\text { Brazilian Zebu cattle (Gyr, } \\
\text { Guzerat, Sindi, Nelore) }\end{array}$ & $\begin{array}{l}\mathrm{B}=0.000-0.136 \\
\mathrm{C}=0.864-1.000\end{array}$ & Da Salva \& Del Lama, 1997 \\
\hline
\end{tabular}

Table 1. The frequencies of as1-casein alleles in various breeds of cattle

The gene CSN1S2 encoding $\alpha$ s2-casein has the length of 18438 nucleotides and is divided into 18 exons ranging from 21 to 266 nucleotides (Ramunno et al., 2001). So far only 4 genetic variants of bovine $\alpha$ s2-casein were described: A, B, C and D. Allele A which was created by 
mutation of allele D exists in most European breeds up to date. Alleles B and C are specific, respectively, for zebu and yaks (Ibeagha-Awemu et al., 2007).

$\beta$-casein is a fraction which forms up to $45 \%$ of bovine caseins in milk. The native milk protease plasmin leads to the creation of $\gamma_{1-}, \gamma_{2}-$ and $\gamma_{3}-\mathrm{CN}$, which are actually fragments of $\beta$-casein consisting of the following sections of the chain 29-209, 106-209 and 108-209 (Farrell et al., 2004). 12 genetic variants that determine the synthesis of this protein were identified so far, i.e. $\mathrm{A}^{1}, \mathrm{~A}^{2}, \mathrm{~A}^{3}, \mathrm{~B}, \mathrm{C}, \mathrm{D}, \mathrm{E}, \mathrm{F}, \mathrm{G}, \mathrm{H}^{1}, \mathrm{H}^{2}$ and $\mathrm{I}$ (Farrell et al., 2004). The reference protein for this family is $\beta$-casein A2-5P consisting of a single chain protein, assembled from 209 amino acids residues without cysteine residues. The most common forms of $\beta$-casein in dairy cattle are $\mathrm{A}^{1}$ and $\mathrm{A}^{2}$, which differ by only one amino acid (Farrell et al., 2004). At the 67 position of amino acid chain, respectively, variant $\mathrm{A}^{1}$ contains histidine and variant $\mathrm{A}^{2}$ proline. Variant $\mathrm{A}^{2}$, however, is the original form and is identified in old breeds of cattle (Zebu, Guernsey), whereas variant $\mathrm{A}^{1}$ evolved much later and is characteristic to contemporary breeds (Hanusova et al., 2010). Variant B is less common, and $\mathrm{A}^{3}$ and $\mathrm{C}$ exist rarely (Farrell et al., 2004). These alleles are most common for European breeds of cattle.

Allele E was only identified for the Italian Piemontese breed. The occurrence of genetic variants is based on nucleotide substitutions within exon VII (A1, A2, A3 and B) and exon VI (C and E) (Jann et al., 2002). Table 2 shows the frequencies of $\beta$-casein alleles in various breeds of cattle.

The $\kappa-\mathrm{CN}$ family consists of a major carbohydrate-free component and a minimum of 6 minor components. The 6 minor components are detected by PAGE in urea with 2mercaptoethanol. In the basic structure of the reference protein of $\kappa-\mathrm{CN}$ family is a major carbohydrate-free component of $\kappa-\mathrm{CN}-1 \mathrm{P}$. It consists of 169 amino acid residues arranged in the following order: Asp4, Asn8, Thr15, Ser12, Ser P1, Pyroglu1, Glu12, Gln14, Pro20, Gly2, Ala14, Cys2, Val11, Met2, Ile12, Leus, Tyr9, Phe4, Lys9, His3, Trp1 and Arg5, with a molecular weight of 19.307 (Farrell et al., 2004). What is more, the length of $\kappa$-casein is less than $13 \mathrm{~kb}$, though most of the coding sequences are comprised in the exon IV. $\kappa$-casein differs significantly from other caseins, both in terms of properties and structure. It is highly homologous to the fibrinogen gamma chain. What is more it serves a similar function, while being a stabilizing factor during the formation of the clot (Azevedo et al., 2008). So far 12 genetic variants of $\kappa-$ casein were identified: A, A 1 , B, C, E, F $\mathrm{F}^{1}, \mathrm{~F}^{2}, \mathrm{G}^{1}, \mathrm{G}^{2}, \mathrm{H}$, I and J (Chen et al., 2008; Farrell et al., 2004). The differences between them are caused by two point mutations involving a substitution of threonine with isoleucine at the 136 position of polypeptide chain and aspartic acid with alanine at the 148 position (Azevedo et al., 2008). What is more, at the Cterminal part of $\kappa$-casein molecule a macropeptide residue can be found (106-169 chain fragment) (Farrell et al., 2004). Numerous studies focused on the analysis of genes that control the frequency of $\kappa-\mathrm{CN}$ polymorphism exhibit a superior frequency of allele $\mathrm{A}$ above allele B - for dairy, meat and also high productivity and local breeds (Król, 2003; Tsiaras et al., 2005). Azewedo et al. (2008) in their research on Brazilian cattle stated that the frequency of allele B of $\kappa$-casein ranges from 0.01 to 0.30 . Kučerova et al. (2006) have also demonstrated a high frequency of allele B (0.38) and genotype BB (13\%) in the population of Czech Fleckvieh cattle. Table 3 shows the frequencies of $\kappa$-casein alleles in various breeds of cattle. 


\begin{tabular}{|c|c|c|}
\hline Cattle breed & $\begin{array}{l}\text { Allelic frequencies of } \beta- \\
\text { casein }\end{array}$ & References \\
\hline Holstein-Friesian & $\begin{aligned} \mathrm{A}^{1} & =0.472 \\
\mathrm{~A}^{2} & =0.496 \\
\mathrm{~B} & =0.026\end{aligned}$ & \multirow{2}{*}{ Ehrmann et al., 1997} \\
\hline Jersey & $\begin{aligned} \mathrm{A}^{1} & =0.093 \\
\mathrm{~A}^{2} & =0.721 \\
\mathrm{~B} & =0.186\end{aligned}$ & \\
\hline Jersey & $\begin{array}{l}\mathrm{A}^{1}=0.123 \\
\mathrm{~A}^{2}=0.591\end{array}$ & $\begin{array}{c}\text { Winkelman \& Wickham, } \\
1997\end{array}$ \\
\hline Polish Red & $\begin{aligned} \mathrm{A}^{1} & =0.617 \\
\mathrm{~A}^{2} & =0.321 \\
\mathrm{~B} & =0.062\end{aligned}$ & \multirow{3}{*}{ Erhardt et al., 1998} \\
\hline Red Danish Dairy Cattle & $\begin{array}{c}\mathrm{A}^{1}=0.710 \\
\mathrm{~A}^{2}=0.230 \\
\mathrm{~B}=0.060\end{array}$ & \\
\hline German Red & $\begin{aligned} \mathrm{A}^{1} & =0.628 \\
\mathrm{~A}^{2} & =0.302 \\
\mathrm{~A}^{3} & =0.013 \\
\mathrm{~B} & =0.057\end{aligned}$ & \\
\hline Estonian Native & $\begin{array}{c}\mathrm{A}^{1}=0.318 \\
\mathrm{~A}^{2}=0.644 \\
\mathrm{~B}=0.038\end{array}$ & \multirow{3}{*}{ Jõuru et al., 2007} \\
\hline Western Finncattle & $\begin{aligned} \mathrm{A}^{1} & =0.292 \\
\mathrm{~A}^{2} & =0.671 \\
\mathrm{~B} & =0.037\end{aligned}$ & \\
\hline Danish Jersey & $\begin{array}{c}\mathrm{A}^{1}=0.094 \\
\mathrm{~A}^{2}=0.688 \\
\mathrm{~B}=0.219\end{array}$ & \\
\hline
\end{tabular}

Table 2. The frequencies of $\beta$-casein alleles in various breeds of cattle

\begin{tabular}{|l|c|c|}
\hline Cattle breed & $\begin{array}{c}\text { Allelic frequencies of } \kappa- \\
\text { casein }\end{array}$ & References \\
\hline \multirow{2}{*}{ Jersey } & $\mathrm{A}=0.110$ & \multirow{2}{*}{ Ren et al., 2011} \\
\hline \multirow{2}{*}{ Holstein } & $\mathrm{B}=0.880$ & \\
\hline \multirow{2}{*}{ Romanian Spotted } & $\mathrm{A}=0.690$ & \multirow{2}{*}{ Ilie et al.,2007 } \\
\cline { 1 - 2 } Brown of Maramures & $\mathrm{B}=0.310$ & \\
\hline
\end{tabular}




\begin{tabular}{|c|c|c|}
\hline Cattle breed & $\begin{array}{l}\text { Allelic frequencies of } \kappa- \\
\text { casein }\end{array}$ & References \\
\hline Holstein-Friesian & $\begin{array}{r}\mathrm{A}=0.940 \\
\mathrm{~B}=0.060\end{array}$ & Tsiaras et al., 2005 \\
\hline Holstein & $\begin{array}{l}A=0.760 \\
B=0.240\end{array}$ & Bonvillani et al., 2010 \\
\hline Simmentaler & $\begin{array}{l}A=0.531 \\
B=0.469\end{array}$ & Feleńczak et al., 2008 \\
\hline Polish Red & $\begin{array}{l}A=0.690 \\
B=0.310\end{array}$ & \multirow{3}{*}{ Erhardt et al., 1998} \\
\hline Red Danish Dairy Cattle & $\begin{array}{l}A=0.810 \\
B=0.190\end{array}$ & \\
\hline German Red & $\begin{array}{l}A=0.642 \\
B=0.288 \\
E=0.070\end{array}$ & \\
\hline $\begin{array}{l}\text { Hereford and crossbreeding } \\
F_{1} \text { and } R_{1} \text { (Black and White } x \\
\text { Hereford) }\end{array}$ & $\begin{array}{l}A=0.722 \\
B=0.277\end{array}$ & \multirow{3}{*}{ Litwińczuk \& Król, 2002} \\
\hline $\begin{array}{l}\text { Limousine and crossbreeding } \\
F_{1} \text { and } R_{1} \text { (Black and White } x \\
\text { Limousine) }\end{array}$ & $\begin{array}{l}A=0.607 \\
B=0.393\end{array}$ & \\
\hline Simmentaler & $\begin{array}{l}A=0.681 \\
B=0.302 \\
E=0.017\end{array}$ & \\
\hline Estonian Native & $\begin{array}{l}A=0.695 \\
B=0.305\end{array}$ & \multirow{5}{*}{ Jõuru et al., 2007} \\
\hline Western Finncattle & $\begin{array}{l}A=0.671 \\
B=0.305 \\
E=0.024\end{array}$ & \\
\hline Danish Jersey & $\begin{array}{l}A=0.512 \\
B=0.488\end{array}$ & \\
\hline Estonian Holstein & $\begin{array}{l}A=0.790 \\
B=0.138 \\
E=0.072\end{array}$ & \\
\hline Estonian Red & $\begin{array}{l}A=0.642 \\
B=0.324 \\
E=0.034\end{array}$ & \\
\hline
\end{tabular}

Table 3. The frequencies of $\kappa$-casein alleles in various breeds of cattle

$\beta$-lactoglobulin is a major whey protein. Bovine BLG gene is located on chromosome 11 (11q28) and is responsible for coding the main whey protein which is $\beta$-lactoglobulin. It consists of 7 exons and its length is approximately $6700 \mathrm{bp}$. 


\begin{tabular}{|c|c|c|}
\hline Cattle breed & $\begin{array}{c}\text { Allelic frequencies of } \beta- \\
\text { lactoglobulin }\end{array}$ & References \\
\hline Jersey & $\begin{array}{l}A=0.320 \\
B=0.680\end{array}$ & \multirow{2}{*}{ Ren et al., 2011} \\
\hline Holstein & $\begin{array}{l}A=0.320 \\
B=0.680\end{array}$ & \\
\hline Czech Fleckvieh & $\begin{array}{l}A=0.511 \\
B=0.489\end{array}$ & Kučerova et al., 2006 \\
\hline Holstein-Friesian & $\begin{array}{l}A=0.480 \\
B=0.520\end{array}$ & Tsiaras et al., 2005 \\
\hline Uruguayan Creole & $\begin{array}{l}\mathrm{A}=0.4938 \\
\mathrm{~B}=0.5062\end{array}$ & Rincón et al., 2006 \\
\hline Polish Red & $\begin{array}{c}A=0.188 \\
B=0.740 \\
C=0,058 \\
I=0,014\end{array}$ & \multirow{3}{*}{ Erhardt et al., 1998} \\
\hline Red Danish Dairy Cattle & $\begin{array}{l}A=0.110 \\
B=0.890\end{array}$ & \\
\hline German Red & $\begin{array}{l}A=0.157 \\
B=0.775 \\
C=0.068\end{array}$ & \\
\hline $\begin{array}{l}\text { Hereford and crossbreeding } \\
\mathrm{F}_{1} \text { and } \mathrm{R}_{1} \text { (Black and White } \mathrm{x} \\
\text { Hereford) }\end{array}$ & $\begin{array}{l}A=0.278 \\
B=0.722\end{array}$ & \multirow{3}{*}{ Litwińczuk \& Król, 2002} \\
\hline $\begin{array}{l}\text { Limousine and crossbreeding } \\
F_{1} \text { and } R_{1} \text { (Black and White } x \\
\text { Limousine) }\end{array}$ & $\begin{array}{l}A=0.520 \\
B=0.480\end{array}$ & \\
\hline Simmentaler & $\begin{array}{l}A=0.379 \\
B=0.621\end{array}$ & \\
\hline Estonian Native & $\begin{array}{l}A=0.314 \\
B=0.686\end{array}$ & \multirow{5}{*}{ Jõuru et al., 2007} \\
\hline Western Finncattle & $\begin{array}{l}A=0.098 \\
B=0.902\end{array}$ & \\
\hline Danish Jersey & $\begin{array}{l}A=0.463 \\
B=0.537\end{array}$ & \\
\hline Estonian Holstein & $\begin{array}{l}A=0.421 \\
B=0.579\end{array}$ & \\
\hline Estonian Red & $\begin{array}{l}A=0.254 \\
B=0.746\end{array}$ & \\
\hline
\end{tabular}

Table 4. The frequencies of $\beta$-lactoglobulin alleles in various breeds of cattle 
The first who discovered its polymorphism were Aschaffenburg and Drewry in 1955 (as cited in El-Hanafy et al., 2010). So far 12 genetic variants of $\beta$-lactoglobulin were identified: A, B, C, D, E, F, G, W, H, I, J and X; they encode different forms of proteins (Farrell et al., 2004). For most cow breeds, both variant A and B are most common and occur with high frequency (Heidari et al., 2009). Mutations in the nucleotide sequence resulting in substituting of amino acids are distributed on 3 exons: exon 2 (allele D), exon 3 (alleles A and B) and exon 4 (alleles A, B and I) (Kamiński, 2001). The differences between variant A and $B$ occur because of the existence of different amino acids at position 64: aspartic acid for variant $A$ and glycine for variant $B$. What is more, at position 118 variant $A$ has valine and variant B alanine (Kučerova et al., 2006). The presence of one of the variants (A or B) significantly influences the physicochemical properties of milk and also raises the actual contents of $\beta$-lactoglobulin (Farrell et al., 2004). Tsiaras et al. (2005) noted the presence of 3 genotypes with the frequencies ranging from 0.25 to 0.47 . What is more, Heidari et al. (2009) calculated the frequencies of $\beta$-lactoglobulin genotypes at the levels of: 0.257 for AA, 0.544 for $\mathrm{AB}$ and 0.198 for $\mathrm{BB}$. Kučerova et al. (2006) observed that the proportion of $\mathrm{AB} \beta-$ lactoglobulin genotype ranged from 49.5 to $66.6 \%$ corresponding to other genotypes: for AA from 18.2 to $26.4 \%$ and for BB from 15.2 to $24.1 \%$. Table 4 shows the frequencies of $\beta-$ lactoglobulin alleles in various breeds of cattle.

$\alpha$-LA gene encoding $\alpha$-lactalbumin is localized on chromosome 5 (BTA5q12-13). $\alpha$ lactalbumin has the length of $3061 \mathrm{bp}$ and it consists of 4 exons. The polymorphism of this gene is revealed in cattle breeds deriving directly from Bos indicus. What is more $\alpha$ lactalbumin appear most commonly in 2 forms: A and B (Kamiński, 2001). In bovine milk the concentration of $\alpha$-lactalbumin varies between 1.2 and $1.5 \mathrm{~g} / \mathrm{l}$ (Farrell et al., 2004). This whey protein has a precise role in the mammary gland. It reacts with the enzyme $\beta-1,4-$ galactosyltransferase to form the lactose synthase complex within the Golgia apparatus. It allows the formation of lactose from glucose and UDP-galactose thank to the modifications in the substrate specificity of $\beta$-1,4-galactosyltransferase. The function of lactose as a main osmolyte of milk and its production demonstrate the importance of this fraction (Farrell et al., 2004).

\subsection{Goats}

Goat milk contains 4 caseins ( $\alpha \mathrm{S}_{1-}, \alpha_{\mathrm{S} 2-}, \beta$ - and $\kappa-$ ) linked with each other encoded respectively by autosomal genes: CSN1S1, CSN1S2, CSN2 and CSN3. They are located on chromosome 4 in the following order: $\alpha \mathrm{s}_{1-}, \beta-, \alpha \mathrm{s}_{2}-$ and $\kappa-$. The CSN1S1 gene encoding $\alpha \mathrm{s}_{1-}$ casein has the most complex construction and has a number of polymorphic sites. It has the size of $16.7 \mathrm{~kb}$ and it consists of 19 exons with a length of 24 to $385 \mathrm{bp}$ and 18 introns with a length of 90 to $1685 \mathrm{bp}$ (Supakorn, 2009).

The gene CSN1S1 in goats presents the highest level of variability of all the casein genes among all species of ruminants that have been analysed. So far 16 genetic variants of $\alpha \mathrm{s}_{1-}$ casein were identified: $\mathrm{A}^{1}, \mathrm{~B}^{1}, \mathrm{~B}^{2}, \mathrm{~B}^{3}, \mathrm{~B}^{4}, \mathrm{C}, \mathrm{E}, \mathrm{F}, \mathrm{G}, \mathrm{H}, \mathrm{I}, \mathrm{L}, \mathrm{M}, \mathrm{N}, 0^{1}$ and $0^{2}$. They probably evolved from 4 original alleles: $\mathrm{A}, \mathrm{B}^{1}, \mathrm{~B}^{2}$ and $\mathrm{W}$. What is more, these different alleles are 
associated with 4 levels of protein synthesis in milk. A high level of $\alpha$ s1-casein (3.5-3.6 g/l) synthesis is connected with "strong" alleles: A, B1, B2, B", B , C, H and L. "Medium" alleles determine the protein synthesis at the levels of 1.1-1.6 g/l, while "weak" alleles are associated with the synthesis only at the amounts of $0.45-0.6 \mathrm{~g} / \mathrm{l}$. "Null" alleles $\left(0^{1}\right.$ and $\left.0^{2}\right)$ account for trace amounts or complete absence of this casein fraction in milk (Caravaca et al., 2008; Ibeagha-Awemu et al., 2005; Moatsu et al., 2006; Veress et al., 2004). Table 5 shows the frequencies of $\alpha$ s1-casein alleles in various breeds of goats.

In the local breeds of goats the frequency of A, B and C alleles (so called "strong" alleles) is generally higher, whereas in typical dairy breeds the frequency of so called "medium" and "weak" alleles exceeds (Barłowska et al., 2007a; Jordana et al., 1996; Torres-Vázquez et al., 2008). Moatsou et al. (2008) analysed the contribution of individual genetic variants of $\alpha \mathrm{s}_{1-}$ casein in goats of local Greek and international breeds (Alpine and Saanen). In their research they presented that in local breeds of goats "strong" alleles exceeded and there were no "weak" and "null" alleles. In the international breeds, however, "medium" variants were in majority, and nearly $1 / 3$ had "weak" and "null" alleles. Table 5 shows the frequencies of $\alpha \mathrm{s}_{1}$ casein alleles in various goat breeds.

Goat's CSN1S2 locus is characterized by a much higher genetic diversity compared to cattle or sheep. So far 8 alleles associated with different level of synthesis of $\alpha$ s2-casein have been identified: alleles A, B, C, E and F are the so called "normal" alleles connected with the synthesis of $\alpha$ s2-casein at the level of $2.5 \mathrm{~g} / \mathrm{l}$; allele $\mathrm{D}$ is an intermediate allele associated with the synthesis of $\alpha \mathrm{s} 2$-casein at the level of $1.25 \mathrm{~g} / \mathrm{l}$; "null" alleles linked to the absence or synthesis of $\alpha$ s2-casein at trace levels. Chessa et al. (2003) presented in their research that the population of Italian dairy goats (Maltese breed) are characterized by the presence of 5 alleles of CSN1S2: A, B, C, G and 0 with the frequencies: 0.548, 0.062, 0.319, 0.067 and 0.005 respectively.

So far 5 alleles of goat's CSN2 gene were identified that are associated with different levels of $\beta$-casein in milk. Alleles A, B and C are connected with normal contents of this protein, while alleles 0 and $0^{\prime}$ are linked with undetectable or trace amounts (Ibeagha-Awemu et al., 2005). Sztankóová et al. (2005) in goats from two local breeds White Short- Haired (WSH) and Brown Short-Haired (BSH) maintained in Czech Republic identified allele A associated with "normal" synthesis of $\beta$-casein and allele 0 connected with a lack of synthesis of $\beta$ casein. Goats in the studied population, however, were not associated with a variant 0 of CSN2.

Goat $\kappa$-casein gene is composed of 5 exons, out of which the portion encoding the mature protein is located in the exon 3 ( 9 amino acids) and exon 4 (162 amino acids). It is assumed that the $\kappa$-casein gene is not evolutionary correlated to milk proteins sensitive to calcium, although it is linked with them. There is a hypothesis that it is related to the fibrinogen (Strzelec \& Niżnikowski, 2009). CSN3 was not considered a multiallelic gene until 1990, when Di Luccia et al. (1990) reported variability (alleles A and B) in an unspecified Italian breed. Since then, 11 following variants of this protein were identified: C, D, E, F, G, H, I, J, K, L and M (Ibeagha-Awemu et al., 2005). Chessa et al. (2003) in the Maltese goat breed 


\begin{tabular}{|c|c|c|c|c|c|c|c|c|c|c|}
\hline \multirow{2}{*}{ Breed } & \multirow{2}{*}{ Country } & \multicolumn{8}{|c|}{ Allel } & \multirow{2}{*}{ References } \\
\hline & & A & B & $\mathrm{C}$ & $\mathrm{D}$ & $\mathrm{N}$ & $E$ & $\mathrm{~F}$ & $\mathrm{D}+\mathrm{O}$ & \\
\hline Toggenburg & Mexico & 0.141 & 0.212 & & & 0.179 & 0.147 & 0.321 & & \multirow{5}{*}{$\begin{array}{l}\text { Torres- } \\
\text { Vázquez et } \\
\text { al., } 2008\end{array}$} \\
\hline $\begin{array}{l}\text { Appearance } \\
\text { of Murciana- } \\
\text { Granadina }\end{array}$ & Mexico & 0.250 & 0.135 & & & 0.058 & 0.442 & 0.115 & & \\
\hline $\begin{array}{l}\text { Mosaico } \\
\text { Lagunero }\end{array}$ & Mexico & 0.183 & 0.350 & & & 0.183 & 0.050 & 0.233 & & \\
\hline Saanen & Mexico & 0.031 & 0.108 & & & 0.072 & 0.418 & 0.371 & & \\
\hline Alpine & Mexico & 0.185 & 0.142 & & & 0.154 & 0.241 & 0.278 & & \\
\hline Alpine & Spanish & 0.14 & 0.05 & 0.01 & 0.34 & & & 0.41 & 0.05 & \multirow{8}{*}{$\begin{array}{l}\text { Jordana et } \\
\text { al., } 1996\end{array}$} \\
\hline $\begin{array}{l}\text { Murciano- } \\
\text { Granadina }\end{array}$ & Spanish & 0.08 & 0.23 & & 0.59 & & & 0.08 & 0.02 & \\
\hline Malagueña & Spanish & 0.09 & 0.09 & & 0.65 & & & 0.04 & 0.13 & \\
\hline Payoya & Spanish & 0.05 & 0.19 & & 0.76 & & & & & \\
\hline Canaria & Spanish & 0.28 & 0.32 & & 0.20 & & & & 0.20 & \\
\hline Palmera & Spanish & 0.68 & 0.23 & & 0.09 & & & & & \\
\hline Majorera & Spanish & 0.07 & 0.38 & & 0.24 & & & & 0.31 & \\
\hline Tinerfeña & Spanish & 0.15 & 0.35 & & 0.32 & & & & 0.18 & \\
\hline Boer & Malaysia & 0.15 & 0.10 & 0.71 & & & & 0.04 & & \multirow{4}{*}{$\begin{array}{l}\text { Marini et } \\
\text { al., } 2011\end{array}$} \\
\hline Boer-Feral & Malaysia & 0.22 & & 0.68 & & & & 0.03 & & \\
\hline Katjang & Malaysia & 0.61 & 0.11 & 0.17 & & & & & & \\
\hline Jamnapari & Malaysia & 0.51 & 0.10 & 0.28 & & & & 0.10 & & \\
\hline $\begin{array}{l}\text { White } \\
\text { improved }\end{array}$ & Poland & 0.252 & 0.285 & & & & 0.463 & & & \multirow{4}{*}{$\begin{array}{l}\text { Barłowska } \\
\text { et al., 2007a }\end{array}$} \\
\hline $\begin{array}{l}\text { Colored } \\
\text { improved }\end{array}$ & Poland & 0.194 & 0.319 & & & & 0.487 & & & \\
\hline $\begin{array}{l}\text { White non- } \\
\text { improved }\end{array}$ & Poland & 0.185 & 0.233 & & & & 0.582 & & & \\
\hline $\begin{array}{l}\text { Colored non- } \\
\text { improved }\end{array}$ & Poland & 0.182 & 0.196 & & & & 0.622 & & & \\
\hline
\end{tabular}

Table 5. The frequencies of $\alpha$ s1-casein alleles in various breeds of goats

characterized 3 alleles of CSN3, i.e. A, B and D with the frequency: 0.089, 0.230 and 0.708 respectively. Sztankóová et al. (2005) in White Short-Haired (WSH) and Brown Short-Haired (BSH) breeds of goats also identified 3 alleles of CSN3, although these were alleles A, B and C. The frequencies of A, B and C alleles were, respectively: $0.15,0.80$ and 0.05 for the WSH breed and 0.52, 0.40 and 0.03 for BSH breed. Bemji et al. (2006) in Nigerian Red Sokoto breed characterized the presence of 3 alleles of CSN3, i.e. A, B and $\mathrm{M}$ with the following frequencies: $0.453,0.523$ and 0.023 . 


\begin{tabular}{|c|c|c|c|}
\hline Breed & $-60 \mathrm{C}$ allele & $-60 \mathrm{~T}$ allele & References \\
\hline Muriciano Grandana & 0.86 & 0.14 & \multirow{5}{*}{ Yahyaoui et al., 2000} \\
\hline Canaria & 1 & - & \\
\hline Payoya & 0.73 & 0.27 & \\
\hline Malguena & 0.75 & 0.25 & \\
\hline Saanen & 0.73 & 0.27 & \\
\hline Hungarian Milk & 0.88 & 0.12 & Veress et al., 2004 \\
\hline
\end{tabular}

Table 6. The frequencies of $\beta$-lactoglobulin in various breeds of goats

Goat's LAA and LBG genes encoding 2 major whey proteins, respectively, $\alpha$-lactalbumin and $\beta$-lactoglobulin, are characterized with much lower genetic variation in comparison to the genes observed in cattle. Goat's LGB gene is located on chromosome 11q28. What is more there is a high homogeneity of $\beta$-lactoglobulin in bovine, ovine and goat (at the level of $95 \%$ ). Sheep and goat $\beta$-lactoglobulin differs itself from bovine $\beta$-lactoglobulin only in 6 positions (Strzelec \& Niżnikowski, 2009; Yahyaoui et al., 2000). Table 6 shows the frequencies of $\beta$-lactoglobulin in various breeds of goats.

\subsection{Sheep}

The research on the analysis of milk protein polymorphism in sheep is limited to the study of the gene polymorphism of $\alpha$ s1-casein and $\beta$-lactoglobulin.

BLG gene in sheep is located on chromosome 3 and three alleles can be found within its area: A, B and C. Alleles A and B (present in all breeds) differ in the substitution of 1 amino acid at position 20 of the polypeptide chain, i.e. for variant $A$ it is tyrosine, while for variant $\mathrm{B}$ it is histidine. Variant $\mathrm{C}$ of $\beta$-lactoglobulin, which is rare, is a subtype of allele A and it was recognized within the German and Spanish Merino breed. It differs from variant A with a substitution of arginine with glutathione at position 148 of the amino acid chain (Arora et al., 2010; El-Shazly et al., 2012; Mohammadi et al., 2006).

Sheep milk contains 4 casein fractions: $\alpha \mathrm{s}_{1-}^{-}, \alpha_{\mathrm{S} 2-}, \beta$ - and $\kappa$ - encoded by the genes: CSN1S1, CSN1S2, CSN2 and CSN3. These genes are localized on chromosome 4. So far 8 alleles of CSN1S1 were identified: A, B, C, D, E, F, G and H (Giambra et al., 2010). Vlaic et al. (2011) evaluating 282 sheep from 5 breeds maintained in Romania: Turcana, Carabasa, Tigaie (white and rusty varieties), Cluj Merinos, Botosani Karakul (black, dark grey, brown, light grey, pink and white varieties) have reported the presence of 2 alleles of BLG, i.e. A and B. The frequencies of alleles ranged: for allele A from 0.422 to 0.800 and for allele B from 0.133 to 0.578. Mroczkowski et al. (2004) in Polish Merino identified: 4 alleles of CSN1S1 (A, B, C and D), 3 alleles for CSN2 (A, B and C) and 2 alleles for $\beta$-lactoglobulin (A and B). They indicated the existence of alleles, respectively: for $\alpha$-lactalbumin only 1 allele A with a frequency of 1.00; for $\alpha$ s1-casein 4 alleles with frequencies of $\mathrm{A}=0.078, \mathrm{~B}=0.007, \mathrm{C}=0.905$ and $\mathrm{D}=0.010$; for $\beta$-casein 3 alleles with frequencies of $\mathrm{A}=0.944, \mathrm{~B}=0.051$ and $\mathrm{C}=0.005$; for $\beta$ lactoglobulin 2 alleles with frequencies of $A=0.498$ and $B=0.502$. 


\subsection{Buffalo}

Buffalo milk is characterized by the presence of all 4 casein fractions ( $\alpha \mathrm{s}_{1-}^{-}, \beta-, \alpha \mathrm{s}_{2}-$ and $\left.\kappa^{-}\right)$ encoded by 4 closely linked autosomal genes (CSN1S1, CSN2, CSN1S2 and CSN3) that are mapped on chromosome 7 (Iannuzzi et al., 2003). These casein fractions are distributed in buffalo milk respectively: $\beta$ - (53.45\%), $\alpha s_{1-}(20.61 \%), \alpha \mathrm{s}_{2}-(14.28 \%)$ and $\kappa-(11.66 \%)$ (Cosenza et al., 2011). What is more, BLG gene is mapped on chromosome 12 (as cited in El Nahas et al., 2001). Ren et al. (2011) assessing the population of 48 water buffaloes identified only the existence of allele B of CSN3 and LBG. Allele A was not present at all for these fractions of protein. Similar results were established by Shende at al. (2009) who were studying the polymorphism of $\kappa$-casein in 20 buffaloes - only allele B of CSN3 was identified.

\section{Milk protein genes as markers of production traits}

The research on determining the relationship between the presence of different genetic markers and production traits of animals is being conducted for many years now. In the livestock farming the emphasis was put on milk protein genes.

\subsection{The association between selected genetic variants with the chemical composition of milk}

\subsubsection{Cattle}

A major milk protein which is considered to be an important genetic marker of quantitative traits is $\beta$-lactoglobulin. Analysing the association of genetic variants of is $\beta$-lactoglobulin with the chemical composition of milk, most authors link the variant $\mathrm{B}$ of $\beta$-lactoglobulin with the higher contents of total protein, casein, fat and dry matter in milk (Barłowska, 2007; Barłowska et al., 2007b; Ng-Kwai-Hang, 2002). Lodes et al. (1997) presented in their research that the gene $\mathrm{B}$ of $\beta$-lactoglobulin led to the increase of total protein in milk (including casein) with the simultaneous decrease of contents of whey proteins. The protein contents, depending on the genotype of $\beta$-lactoglobulin was reduced, respectively: for total protein $\mathrm{BC}>\mathrm{AD} / \mathrm{BB}>\mathrm{AB}>\mathrm{AA} / \mathrm{BD}$; for casein - $\mathrm{BC}>\mathrm{BB}>\mathrm{AD} / \mathrm{AB} / \mathrm{BD}>\mathrm{AA}$; for whey protein $\mathrm{AA}>\mathrm{AD}>\mathrm{AB}>\mathrm{BC}>\mathrm{BD}>\mathrm{BB}$. A similar relationship was ascertained by Bonfatti et al. (2010) who conducted research on 2167 cows of the Simmental breed maintained in 47 herds in Northern Italy. They have also reported the positive influence of allele B of $\beta$-lactoglobulin on the percentage contribution of all casein fractions and $\alpha$-lactalbumin and negative effect on the contents of $\beta$-lactoglobulin. Contrary to that research, Hallen et al. (2008) presented a negative association of variant $B$ of $\beta$-lactoglobulin with the concentration of total protein.

Ryniewicz et al. (1998) in their research showed that the physical structure, i.e. the compactness of the casein curd connected with the ease and speed of its digestion, is associated with the polymorphic forms of milk proteins. What is more, milk with $A B$ heterozygotes of $\beta$-lactoglobulin has the most digestible protein which may be associated 
with better results of rearing of offspring from cows with this genotype. This fact is confirmed by the studies of Litwińczuk \& Król (2002) and Król (2003) who evaluated the cows of the Limousine and Hereford breeds; the research focused on calves to the age of approximately 8 months. The average daily gains of calves reared by cows of the Hereford breed with $\mathrm{AB}$ genotype of $\beta$-lactoglobulin (861.3 g) were $115.7 \mathrm{~g}$ higher in comparison to the increments of calves reared by cows with AA genotype and $33 \mathrm{~g}$ higher compared to $\mathrm{BB}$ homozygotes of $\beta$-lactoglobulin. Higher daily gain of calves with $\mathrm{AB}$ genotype of $\beta$ lactoglobulin led to higher body weight at the age of 210 days $(207.4 \mathrm{~kg})$ in comparison to BB $(192.7 \mathrm{~kg})$ and AA $(184.1 \mathrm{~kg})$ homozygotes. Similar results were presented in Henderson \& Marshall (1996) studies on the multi-breed population of beef cattle. They stated that the best results of rearing calves were achieved by cows with the $\mathrm{AB}$ and $\mathrm{BB}$ genotypes of $\beta$ lactoglobulin.

A milk protein which arouses the greatest interest as a genetic marker is $\kappa$-casein. On the one hand (Barłowska et al., 2007b; Litwińczuk et al., 2006; Winkelman \& Wickham, 1997) in their studies link AA genotype of $\kappa$-casein with a higher yield of milk. On the other hand Creamer \& Harris (1997) present that the highest daily yield of milk is obtained from cows with AB genotype of $\kappa$-casein. Król (2003) who conducted research on beef cattle of the Hereford breed has also concluded that the highest milk yield was associated with the $A B$ genotype of $\kappa$-casein. Henderson \& Marshall (1996), who analysed the characteristics of milk yield in the multi-breed population of beef cattle in South Dakota, stated that the cows with $\mathrm{AB}$ and $\mathrm{AA}$ genotypes of $\kappa$-casein produced the most milk and BB homozygotes of $\kappa$-casein the lowest quantity. Lodes et al. (1997) within 7 genotypes of $\kappa$-casein, i.e. AA, AB, AC, AE, $\mathrm{BB}, \mathrm{BC}$ and $\mathrm{BE}$ did not describe significant differences in the productivity of dairy cows. Some authors point to a higher concentration of total protein (including casein) and fat in milk from cows of BB homozygotes of $\kappa$-casein (Barłowska, 2007; Karima et al., 2010). Henderson \& Marshall (1996) also indicate the relationship between genetic variants of $\kappa-$ casein with the results of rearing calves.

The progeny of cows with $\mathrm{AB}$ genotype of $\kappa$-casein achieved the highest daily gain (932 $\mathrm{g}$ ) and the highest body weight at the peak $(242 \mathrm{~kg})$. Similar results were presented in the research of Król (2003) who carried it out on cows of the Hereford and Limousine breed.

In most studies focused on the analysis of genotype of $\alpha$ s1-casein and $\beta$-casein no clear significant relation of these genetic variants on cow productivity (and contents of protein and casein in milk) was presented (Huang et al., 2012; Ikonen et al., 2001; Litwińczuk \& Król, 2002). Only the variant $C$ of $\alpha$ s1-casein is associated with a slightly higher contents of protein and casein in milk in comparison to allele B of as1-casein (Winkelman \& Wickham, 1997). McLean (1984) indicates the connection of variant C of $\alpha$ s1-casein with a higher concentration of $\alpha$ s1-casein and also with a simultaneous decrease of $\kappa$-casein in milk.

In the case of $\beta$-casein the research is mainly focused on the subfraction $A$ of $\beta$-casein, i.e. $A^{1}$, $\mathrm{A}^{2}, \mathrm{~A}^{3}$. Most studies (Nilsen et al., 2009; Olenski et al., 2010; Winkelman \& Wickham, 1997) indicate the positive association of variant $\mathrm{A}^{2}$ of $\beta$-casein on milk yield and the contents of protein. According to Nilsen et al. (2009) and Olenski et al. (2010) $\mathrm{A}^{2}$ allele of $\beta$-casein is an 
effective genetic marker for the productivity of proteins. They suggest conducting a selection of cattle to raise its frequency. Table 7 shows the association of genetic variants of cattle milk proteins with milk yield and its composition.

\begin{tabular}{|c|c|c|c|}
\hline \multirow[t]{2}{*}{ Item } & \multicolumn{3}{|c|}{ Protein fraction } \\
\hline & $\beta-\mathrm{LG}$ & $\kappa-\mathrm{CN}$ & $\alpha \mathrm{s} 1-\mathrm{CN}$ \\
\hline Milk yield & $\begin{array}{l}\text { AA>BB>AB (Creamer } \\
\& \text { Harris, 1997; } \\
\text { Walawski et al., 1994) } \\
\text { AB>AA>BB } \\
\text { (Henderson \& } \\
\text { Marshall, 1996; Król, } \\
\text { 2003) }\end{array}$ & $\begin{array}{l}\text { AB>AA>BB (Creamer } \\
\text { \& Harris, 1997; } \\
\text { Henderson \& Marshall, } \\
\text { 1996; Król, 2003) } \\
\text { AA>AB>BB } \\
\text { (Litwińczuk et al., 2006) }\end{array}$ & $\begin{array}{l}\text { no distinct tendency } \\
\text { between genotypes }\end{array}$ \\
\hline Total protein & $\begin{array}{l}\mathrm{BB}>\mathrm{AB}>\mathrm{AA} \text { (Lunden et } \\
\text { al., 1997; Ng-Kwai- } \\
\text { Hang, 2002) } \\
\text { AA/AB }>\text { BB (Creamer \& } \\
\text { Harris, 1997; Hallen et } \\
\text { al., 2008) }\end{array}$ & $\begin{array}{l}\text { BB }>A B>A A \text { (Barłowska } \\
\text { et al., 2007b; Creamer \& } \\
\text { Harris, 1997; Feleńczak } \\
\text { et al., 2004, Karima et } \\
\text { al., 2010) }\end{array}$ & $\begin{array}{l}\text { CC/BC>BB (Winkelman } \\
\text { \& Wickham, 1997) }\end{array}$ \\
\hline Casein & $\begin{array}{l}\mathrm{BB}>\mathrm{AB}>\mathrm{AA} \text { (Bonfatti et } \\
\text { al., 2010, Creamer \& } \\
\text { Harris, 1997; Heck et } \\
\text { al., 2009) }\end{array}$ & $\begin{array}{l}\mathrm{BB}>\mathrm{AB}>\mathrm{AA}(\mathrm{Creamer} \\
\& \text { Harris, 1997; } \\
\text { Feleńczak et al., 2004, } \\
\text { Karima et al., 2010) }\end{array}$ & $\begin{array}{l}\text { CC/BC>BB (Winkelman } \\
\& \text { Wickham, 1997) }\end{array}$ \\
\hline Whey protein & $\begin{array}{l}\text { AA }>\text { AB }>\text { BB (Creamer } \\
\& \text { Harris, 1997; Lunden } \\
\text { et al., 1997) }\end{array}$ & $\begin{array}{l}\mathrm{AA}>\mathrm{AB}>\mathrm{BB}(\text { Creamer } \\
\& \text { Harris, 1997) }\end{array}$ & $\begin{array}{l}A B>B B>B C(\text { Creamer \& } \\
\text { Harris, 1997) }\end{array}$ \\
\hline Fat & $\begin{array}{l}B B>A B>A A(N g-K w a i- \\
\text { Hang, 2002) }\end{array}$ & $\begin{array}{l}B B>A B>A A \text { (Barłowska } \\
\text { et al., 2007b; Karima et } \\
\text { al., 2010) }\end{array}$ & $\begin{array}{l}\text { no distinct tendency } \\
\text { between genotypes }\end{array}$ \\
\hline
\end{tabular}

Table 7. The association of genetic variants of cattle milk proteins with milk yield and its composition

\subsubsection{Goats}

From all polymorphic proteins in goats the most known is definitely $\alpha \mathrm{s}_{1}$-casein. In most studies, no significant correlation between the variants of $\alpha$ si-casein and milk productivity was ascertained linking this with a strong influence of various factors such as age, stage of lactation etc. (Barłowska et al., 2007a; Litwińczuk et al., 2007; Remeuf, 1993). Some authors, however (Ryniewicz et al., 2000; Vassal \& Manfredi, 1994), indicate a lower daily milk yield from goats with a variant $\mathrm{E}$ of $\alpha \mathrm{s} 1$-casein. Most of the studies on goat milk were focused on the analysis of the association of polymorphic variants of as1-casein with the chemical composition of milk and its technological properties (Barłowska et al., 2007a; Clark \& Sherbon, 2000; Remeuf, 1993; Schmidely et al., 2002). A positive influence of "strong" 
variants (A, B and C) of as1-casein on the concentration of particular milk components (especially proteins) was demonstrated (Barłowska et al., 2007a; Krzyżewski et al., 2000; Litwińczuk et al., 2004; 2007b; Remeuf, 1993; Schmidely et al., 2002; Vassal \& Manfredi, 1994). Krzyżewski et al. (2000) analysing the population of White improved breed of goats indicated a higher contents of protein (about $0.15 \%$ more) in the milk of goats characterized by "strong" polymorphic variants of as1-casein in comparison to animals with "medium" variants. In the studies conducted by Litwińczuk et al. (2004) on goats originating from the region of Wielkopolska and Podkarpacie differences in total protein contents between goats with "strong" and "medium" variants ranged from 0.29 to $0.39 \%$. Schmidely et al. (2002) compared the chemical composition of homozygotes AA and FF of as1-casein of the Alpine and Sannen breeds and showed that the animals with AA genotype produced milk with a higher contents of fat (about $1.2 \mathrm{~g} / \mathrm{kg}$ more) and protein (about $6.3 \mathrm{~g} / \mathrm{kg}$ more) in comparison to goats with FF homozygotes.

A propitious relationship between "strong" $\alpha$ s1-casein genotypes and contents of fat and protein in milk was also described in the research of Barłowska et al. (2007a and 2007c) conducted on goats of 4 breeds. Moreover, a clear association of $\alpha$ s1-casein genotypes with the concentration of casein was indicated. In a group of goats with the highest contents of casein in milk ( $\geq 2.4 \%$ ) in each breed goats with "strong" genotypes (AA, AB, BB, AE and $\mathrm{BE})$ were predominant - in comparison to animals with "medium" genotypes the prevalence ranged from $7.2 \%$ (for coloured non-improved breed) to $29.1 \%$ (for white improved breed of goats). The opposite situation was observed for samples containing the lowest amounts of casein ( $\leq 1.99 \%)$. In every breed goats with "medium" genotypes of $\alpha s_{1}$ casein dominated. Their prevalence ranged from $7.9 \%$ for white non-improved breed to 19.0 $\%$ for coloured improved breed. According to Vassal \& Manfredi (1994) the contents of casein in milk depending on the different alleles of as1-casein varies, respectively: for "strong" alleles, i.e. A, B and C- $3.6 \mathrm{~g} / \mathrm{l}$; for "medium" alleles, i.e. E and G - $1.6 \mathrm{~g} / \mathrm{l}$; for "weak" alleles, i.e. D and F - approximately $0.6 \mathrm{~g} / \mathrm{l}$. The presence of "null" variant is related to the synthesis of trace amounts or the complete absence of this fraction.

Genetic variants of $\alpha$ s1-casein are not only associated with the protein contents in milk but also with their quantitative proportions both within $\alpha$ s1-casein and the rest of proteins from casein group. What is more, milk from goats with "strong" alleles of as1-casein contains more Ca and Zn (Krzyżewski et al., 2002).

Ryniewicz et al. (1998) also presented a relationship between polymorphic variants of $\alpha s_{1-}$ casein and susceptibility of total protein to hydrolysis. Significantly higher degree of hydrolysis of protein was determined in the milk of goats characterized by "weak" variants of $\alpha$ s1-casein.

\subsubsection{Sheep}

Most studies conducted on ovine milk concern the association of polymorphic variants of $\alpha$ s1-casein, $\beta$-casein and $\beta$-lactoglobulin on the chemical composition of milk. It was 
indicated that sheep with CC genotype of $\alpha$ s1-casein are characterized by a higher contents of base composition. In the studies conducted on the population of the Polish Merino and Polish Merino x Prolific sheep (Mroczkowski et al., 2002) it was determined that milk obtained from CC homozygotes of $\alpha \mathrm{s}_{1}$-casein contained significantly more protein and dry matter in comparison to $\mathrm{AC}$ and $\mathrm{BC}$ heterozygotes. What is more, $\mathrm{BC}$ genotype of asi-casein was associated with a higher milk production.

There are not many studies concerning the relationship between polymorphic variants of $\beta$ casein and the composition of milk. In the research of Mroczkowski et al. (2004) sheep with AA genotype of $\beta$-casein were characterized by a higher contents of protein and dry matter in comparison to individuals with $\mathrm{AB}$ genotype of $\beta$-casein. However, $\mathrm{AB}$ heterozygotes of $\beta$-casein corresponded to a higher milk production.

The results of Mroczkowski et al. (2004) indicate that the AA and BB homozygotes of $\beta$ lactoglobulin were characterized by higher yields of milk and contents of protein and casein than AB heterozygotes. In the research of Nudda et al. (2000) who analysed the milk of Sarda sheep, it was stated that the genetic variants of $\beta$-lactoglobulin have an association with only the milk yield, i.e. animals with $\mathrm{AB}$ genotype of $\beta$-lactoglobulin were considered to have the highest daily production. The results of other authors are presented in the Table 8.

\begin{tabular}{|c|c|c|}
\hline \multirow[t]{2}{*}{ Item } & \multicolumn{2}{|c|}{ Protein fraction } \\
\hline & $\beta-\mathrm{LG}$ & $\alpha \mathrm{s} 1-\mathrm{CN}$ \\
\hline Milk yield & $\begin{array}{l}\text { AA/BB }>\text { AB (Mroczkowski et al., } \\
\text { 2004) } \\
\text { AB }>\text { AA }>\text { BB (Nudda et al., 2000) }\end{array}$ & $\begin{array}{c}\text { BC }>C C>C D(\text { Chianesse et al., 1996) } \\
\text { BC }>\text { AC }>C C \text { (Mroczkowski et al., 2002) }\end{array}$ \\
\hline $\begin{array}{l}\text { Total } \\
\text { protein }\end{array}$ & $\begin{array}{c}\text { BB }>\text { AB }>\text { AA (Krukovics et al., 1998; } \\
\text { Mroczkowski et al., 2002) }\end{array}$ & $\begin{array}{c}\mathrm{CC}>\mathrm{CD}>\mathrm{BC}(\text { Chianesse et al., 1996) } \\
\mathrm{CC}>\mathrm{AC}>\mathrm{BC} \text { (Mroczkowski et al., 2002) }\end{array}$ \\
\hline Casein & BB $>$ AB $>$ AA ( Krukovics et al., 1998) & CC>CD>BC (Chianesse et al., 1996) \\
\hline Fat & $\begin{array}{l}\text { no distinct tendency between } \\
\text { genotypes }\end{array}$ & $\begin{array}{c}\text { CC }>\text { AC }>\text { BC (Mroczkowski et al., 2002; } \\
\text { Mroczkowski et al., 2004) }\end{array}$ \\
\hline
\end{tabular}

Table 8. The association of genetic variants of ovine milk proteins with the milk yield and chemical composition

\subsection{The association between selected genetic variants with the parameters of technological suitability of milk}

\subsubsection{Cattle}

For cattle, polymorphic forms of $\kappa$-casein and $\beta$-lactoglobulin are strongly associated with the parameters of technological suitability of milk.

Many studies emphasize the distinct association of genetic variants of $\beta$-lactoglobulin with the chemical composition of milk and cheese yield. Most of the authors combine BB variant of $\beta$-lactoglobulin with the higher contents of fat in milk (Barłowska, 2007; Barłowska et al., 
2007b; Ng-Kwai-Hang, 1997), protein (Ng-Kwai-Hang, 2002), casein (Lunden et al., 1997), dry matter and also with the higher cheese yield as well as better thermal stability of milk (Imafidon \& Ng-Kwai-Hang, 1991). Lodes et al. (1997) analysing the chemical composition of milk obtained from 801 cows demonstrated that among 7 genotypes of $\beta$-lactoglobulin the highest protein contents was associated with animals with $\mathrm{BC}(3.76 \%)$ genotype of $\beta$ lactoglobulin, and the highest casein contents with BC (2.97\%) and BB (2.85\%) genotypes of $\beta$-lactoglobulin. What is more, BW genotype of $\beta$-lactoglobulin was characterized with the lowest amount of protein (3.44 \%) and casein (2.68 \%). In their research Vătăşescu-Balcan et al. (2007) presented that the BB homozygotes of $\beta$-lactoglobulin are associated with the production of milk rich in fat and protein and therefore very valuable in the manufacture of cheese. According to Creamer \& Harris (1997) variant A of $\beta$-lactoglobulin contributes (in contrary to variant B) to the formation of more concise clot at approximate $\mathrm{pH}$ of 7 . Variant B, in turn, is associated with faster thermal coagulation of milk. Imfidon \& Ng-Kwai-Hang (1991) also claim that the milk obtained from cows with AA genotype of $\beta$-lactoglobulin is more resistant to high temperatures. In studies of Barłowska (2007) it was presented that the best properties in terms of contents of protein (including casein), fat and dry matter was found in milk obtained from cows with genotypes $\mathrm{AA}$ or $\mathrm{AB}$ of $\beta$-lactoglobulin (which means that the variant $A$ was present). Milk from cows with BB genotype of $\beta$-lactoglobulin indicated the shortest $(\mathrm{p} \leq 0.05)$ time of rennet coagulation. However, milk from animals with heterozygotes $(\beta$-LG $\mathrm{AB})$ was characterized by the longest heat treatment stability, i.e. about $29 \mathrm{~s}$ longer related to AA homozygotes of $\beta$-lactoglobulin ( $\mathrm{p} \leq 0.05)$.A more explicit studies are formulated by authors presenting an association of genetic variants of $\kappa$-casein with milk composition and its suitability for cheese production. Most of them (Azevedo et al., 2008; Feleńczak et al., 2004; FitzGerald, 1996; Imafidon \& Ng-Kwai-Hang, 1991; Lunden et al., 1997; Tsiaras et al., 2005) indicate the fact that cows with BB genotype of $\kappa$-casein produce milk with a higher contents of total protein and casein. In addition, this genotype increases the fat contents in milk, provides better stability of casein micelles, shorter time of flocculation, firmer clot formation and higher cheese yield. So that, it can be concluded that genes coding the synthesis of $\kappa$-casein have an influence on technological processes in cheese-making. Barłowska et al. (2007b) stated in their research that the presence of B variant of $\kappa$-casein in cows (of the Polish Red and White-back breed) favourably affects the contents of dry matter, total protein, casein and also it reduces the time of enzymatic coagulation and prolongs the colloidal stability of milk. According to Robitaille et al. (2001) the genetic polymorphism in the gene expression of $\kappa$-casein may influence the physicochemical properties of casein micelles (it is a component stabilizing micelles) and thus the technological properties of milk. What is more, BB genotype not only affects the increase of stability of casein micelles but also quantities of casein (in which it increases the contents of $\kappa$-casein fraction within all caseins). FitzGerald (1996) in his research presented that from milk with BB genotype of $\kappa$-casein it is possible to achieve higher yields of cheese (Edam, Gouda, Cheddar, Mozzarella). This may be associated with a higher fat recovery from cheeses manufactured from that milk. In the research of Imafidon \& Ng-Kwai-Hang (1991) it was presented that milk with BB genotype of $\kappa$-casein is more resistant to heat treatment. 
Four casein loci (CSN1S1, CSN2, CSN1S2 and CSN3) are closely linked and conduct as one genetic unit, thus form different combinations of alleles (haplotypes). According to Matajicek et al. (2007) 15 combinations of $\kappa$-casein and $\beta$-lactoglobulin were identified and the most frequent were $\mathrm{AB} / \mathrm{AB}(21.0 \%)$ and $\mathrm{AA} / \mathrm{AB}(18.3 \%)$. What is more, $\mathrm{BB} / \mathrm{AA}$ genotype was determined to have the highest positive association with the evaluated properties of milk. $\mathrm{AB} / \mathrm{BB}, \mathrm{BB} / \mathrm{BB}, \mathrm{BB} / \mathrm{AB}$ and $\mathrm{AB} / \mathrm{AB}$ genotypes also had a positive correlation with the quality of milk and its clotting properties, whereas genotypes with allele $\mathrm{E}$ of $\kappa$-casein negatively affected these parameters. It was presented that the distribution of allele $\mathrm{A}$ in the combination of $\kappa$-casein and $\beta$-lactoglobulin genotypes resulted in the increase of milk yield, while the presence of allele B was associated with increased contents of protein and fat in milk. Comin et al. (2008) indicated that $\kappa$-casein and $\beta$-lactoglobulin genotypes had a strong relationship with parameters of milk coagulation but not with fat and protein contents and other parameters of milk quality. The best results affecting the clotting of milk were these combinations of $\kappa$-casein and $\beta$-lactoglobulin that contained at least 1 allele B in both loci. $\kappa$-casein locus was more strongly associated with milk coagulation parameters, whereas $\beta$-lactoglobulin was more connected with milk yield and proteins.

\subsubsection{Goats}

Many studies (Barłowska et al., 2007a,c; Devold et al., 2010; Remeuf, 1993; Mahé et al., 1994; Strzałkowska et al., 2004) indicate a strong relationship between genetic variants of CSN1S1 with the chemical composition of milk, mainly the contents of casein, but also with its technological parameters important for cheese production. Homozygous goats with "strong" alleles of CSN1S1 produce milk with significantly higher percentage of protein, fat, calcium and a small diameter of casein micelles. It is possible to acquire more cheese from this type of milk and the curd is more concise in comparison to milk obtained from homozygous goats with "medium" and "weak" alleles. Sacchi et al. (2005) reported that goats with "strong" alleles of $\alpha$ s1-casein $\left(\mathrm{A}, \mathrm{B}^{1}, \mathrm{~B}^{2}, \mathrm{~B}^{3}, \mathrm{~B}^{4}, \mathrm{C}, \mathrm{H}, \mathrm{L}, \mathrm{M}\right)$ synthetize this protein fraction on the level of $3.5 \mathrm{~g} / \mathrm{l}$ of milk. For "medium" (E, J) alleles this value is lower and reaches the level of $1.1 \mathrm{~g} / \mathrm{l}$ of milk and for "weak" alleles $(\mathrm{F}, \mathrm{G})$ it is close to $0.45 \mathrm{~g} / \mathrm{l}$ of milk. In the case of "null" alleles $\left(0^{1}, 0^{2}, \mathrm{~N}\right)$ this protein is not synthetized. This fact is explained by morphological observations at a cellular level of mammary tissue performed by Martin et al. (1999). It was reported that epithelial cells of homozygous goats with "weak" alleles of $\alpha \mathrm{s}_{1}$ casein (E, F, G and O) were characterized by a dramatic swelling of the rough endoplasmic reticulum mainly due to the accumulation of proteins, what strongly suggests a dysfunction in secretion mechanisms. In similar studies Barłowska et al. (2007a) indicated that a group of animals produced milk with the highest contents of casein (over $2.4 \%$ ) and protein (over 3.0 $\%)$ and individuals with "strong" $\alpha$ s1-casein variants were predominant. They constituted approximately $70 \%$ (as for protein) and over $85 \%$ in a group of goats which milk was associated with the highest casein level. A contrary tendency was observed in a group of goats producing milk with low protein $(\leq 2.4 \%)$ and casein $(\leq 2.0 \%)$ contents. There, the individuals with "medium" $\alpha$ s1-casein genotypes (57 - $59 \%$ ) predominated. According to 
Pierre et al. (1996) goat milk with AA genotype of $\alpha$ s1-casein indicated a higher contents of total nitrogen and fat compared to milk obtained from goats with 00 genotype. Cheeses of this type of milk were also more firm, had a higher yield and contained less volatile aromatic compounds. In the research of Clark \& Sherbon (2000) it was presented that the milk obtained from goats with at least 1 "strong" ( $\mathrm{B}^{1}, \mathrm{~B}^{2}, \mathrm{~B}^{3}$ or $\left.\mathrm{C}\right)$ genetic variant of $\alpha \mathrm{s}_{1}$ casein contained more dry matter, SNF, protein and $\alpha$ s1-casein compared to the milk of goats with "weak" variants of $\alpha$ s1-casein (F or D) or homozygotes with "null" variants of $\alpha$ s1-casein (00). However, genetic variants of $\alpha$ s1-casein were not closely correlated with milk coagulation properties. According to Pop et al. (2008) formation of the characteristic "goat flavour" is also associated with the genotype of $\alpha$ s1-casein (CSN1S1). Cheese manufactured from milk with AA genotype has a weaker "goat flavour" compared to the one produced from milk with FF genotype. This is explained by the fact that goat milk with FF genotype of CSN1S1 has a higher lipase activity in comparison to milk obtained from goats with AA genotype. There is relatively little research that clarifies the relationship of genetic variants of $\kappa$-casein with the technological parameters of goat milk. According to Chiatti et al. (2007) genetic variants of $\kappa$-casein may have an association with the contents of protein in milk (including casein) in the following trend: $B B>A B>A A$.

\subsubsection{Sheep}

There is not much research explaining the relationship of genetic variants of ovine milk proteins with the technological parameters of milk. Only in a few studies the correlation between $\beta$-lactoglobulin variants and base chemical composition was demonstrated. Çelük \& Zdemür (2006) evaluating the Awassi and Morkaraman breeds demonstrated that genetic variants of $\beta$-lactoglobulin were only associated with the contents of protein and fat in the milk of Awassi sheep, but had no relation to the contents of dry matter, acidity and milk coagulation time in 2 breeds of sheep.

\section{The modification of milk composition through genetic engineering}

The measures to modify the chemical composition of milk in order to achieve the desired health benefits or processing properties are of increasing importance in dairy biotechnology. The mammary gland is a bioreactor which allows manufacturing of proteins of foreign species. One of the possible changes in the milk composition is the introduction of new or the development of existing milk protein genes which may increase the nutritional value of the product or improve its properties as a raw material for processing (for example by genetic modification of milk it is possible to increase the heat resistance). It is also possible to use the process of "humanization" of cow's milk by the partial replacement of the cattle proteins with those of a human. An important modification of milk is a reduction of lactose contents which adversely affects the quality of cheeses and other dairy products and is not well tolerated by many people as a food ingredient. The decrease of lactose contents in milk may be achieved by inactivating or reducing the expression of $\alpha$-lactalbumin gene or by introducing active in the mammary gland lactase gene or bacterial $\beta$-galactosidase gene 
(lacZ gene). Studies are also conducted towards reducing or eliminating the contents of the main allergen of cow milk, which is $\beta$-lactoglobulin, through the inhibition of expression of BLG gene (knock-out). This protein is not present in human milk (Charon \& Świtoński, 2000). The progress in the identification of genetic engineering methods utilized in dairy biotechnology will depend, in the near future, not only on the development of molecular biology but mainly on the social acceptance of the research in this area.

\section{Conclusion}

The extensive use of the achievements of biological and zootechnical sciences in the second half of twentieth century made it possible to attain a significant increase in the productivity of animals. What is more, the wide and easy access to molecular technologies has influenced the evaluation of animals in a way that the practical use of polymorphism of genes as markers of functional traits is commonly utilized. One of such examples is the polymorphism of milk proteins. The available bibliography suggests that these issues were analysed in all four main species of animals determining the global production of milk, i.e. in cattle, buffaloes, goats and sheep, though the cattle have been examined to the greatest extent.

The milk protein of greatest interest as a genetic marker in cattle is the $\kappa$-casein, whereas in goats it is $\alpha$ s1-casein. Based on the results of many studies it is assumed that AA genotype of $\kappa$-casein is associated with higher milk production, while the BB genotype with higher contents of base chemical composition (proteins, including casein and fat). This genotype is also related to higher stability of casein micelles, shorter flocculation, firmer clot formation and consequently with a better performance of cheese. In the case of goats, a positive association between variants of "strong" (A, B, C) alleles of $\alpha$ s1-casein with the composition of milk was demonstrated. Homozygous goats with "strong" alleles of CSN1S1 produced milk with higher contents of proteins, calcium, fat and with a smaller diameter of casein micelles. From the milk of these goats it is possible to obtain more cheese and the curd is more firm in comparison to homozygous goats with "medium" and "weak" alleles of $\alpha$ s1casein. Similar dependences were not observed in sheep and buffaloes, perhaps because of the lack of research in that area.

\section{Author details}

Barłowska Joanna, Wolanciuk Anna, Litwińczuk Zygmunt and Król Jolanta University of Life Sciences in Lublin, Poland

\section{References}

Arora, R., Bhatia, S., Mishra, B. P., Sharma, R., Pandey, A. K., Prakash, B. \& Jain, A. (2010). Genetic Polymorphism of the $\beta$-Lactoglobulin Gene in Native Sheep from India. Biochem. Genet., Vol. 48, pp. 304-311 
Azevedo, A. L. S., Nascimento, C. S., Steinberg, R. S., Carvalho, M. R. S., Peixoto, M. G. C. D., Teodoro, R. L., Verneque, R. S., Guimarães, S. E. F. \& Machado, M. A. (2008). Genetic polymorphism of the kappa-casein gene in Brazilian cattle. Genet. Mol. Res., Vol. 7, No. 3, pp. 623-630

Bai, W. L., Yin, R. H., Zhao, S. J. Y., Zheng, C., Zhong, J. C. \& Zhao, Z. H. (2008). Short Communication: Characterization of a $\kappa$-Casein Genetic Variant in the Chinese Yak, Bos grunniens. J. Dairy Sci., Vol. 91, pp. 1204-1208

Barłowska, J. (2007). Nutritional value and technological usability of milk from cows of 7 breeds maintained in Poland. Post-DSc dissertation. Lublin, Poland: Agriculture Academy in Lublin. Available from Univ. of Life Sciences in Lublin.

Barłowska, J., Litwińczuk, Z., Florek, M. \& Kędzierska-Matysek, M. (2007a). Milk yield and its composition of 4 Polish goat breeds with different genotypes of $\alpha$ s1-casein (in Polish). Vet. Med., Vol. 63, No. 12, pp. 1600-1603

Barłowska, J., Litwińczuk, Z., Kędzierska-Matysek, M. \& Litwińczuk, A. (2007c). Polymorphism of caprine milk $\alpha$ s1-casein in relation to performance of four Polish goat breeds. Pol. J Vet Sci., Vol. 10, No. 3, pp. 159-163

Barłowska, J., Litwińczuk, Z., Król, J. \& Kędzierska-Matysek, M. (2007b). Relationship of $\beta$ lactoglobulin and $\kappa$-casein genetical variants with chosen indexes of milk technological usefulness of Red Polish and Whitebacks cows. Ann. Anim. Sci., suppl. 1, pp. 43-47

Bemji, M. N., Ibeagha-Awemu, E. M., Osinowo, O. A. \& Erhard, G. (2006). Casein (CSN3) variability of the Nigerian Red Sokoto goat. Nigerian J. Genet. Vol. 20, pp. 1-6

Beuzen, N. D., Stear, M. J. \& Chang, K. C. (2000). Molecular markers and their use in animal breeding. Vet. J., Vol.160, pp. 42-52

Bogdzińska, M. (2011). The utilization of the latest achievements of genetics in the improvement of functional characteristics of the animals (in Polish). Anim. Prod. Rev., No. 6, pp. 2-4

Boichard, D., Grohs, C., Bourgeois, F., Cerqueira, F., Faugeras, R., Neau, A., Rupp, R., Amigues, Y., Boscher, M. Y. \& Levéziel, H. (2003). Detection of genes in sequencing economic traits in three French dairy cattle breeds. Genet. Sel. Evol., 35, pp. 77-101

Bonfatti, V., Di Martino, G., Cecchinato, A., Vicario, D. \& Carnier, P. (2010). Effect of $\beta$ - $\kappa-$ casein (CSN2-CSN3) haplotypes and $\beta$-lactoglobulin (BLG) genotypes on milk production traits and detailed protein composition of individual milk of Simmental cows. J. Dairy Sci., Vol. 93, pp. 3797-3808

Bonvillani, A. G., Di Renzo, M. A. \& Tiranti, I. N. (2010). Genetic polymorphism of milk protein loci in Argentinian Holstein cattle. Genet. Mol. Biol., Vol. 23, No. 4, pp. 819-823

Caravaca, F., Amills, M., Jordana, J., Angiolillo, A., Agüera, P., Aranda, C., MenéndezBuxadera, Sánchez, A., Carrizosa, J., Urrutia, B., Sànchez, A. \& Serradilla, J. M. (2008). Effect of $\alpha$ s1-casein (CSN1S1) genotype on milk CSN1S1 content in Malagueña and Murciano-Granadina goats. J. Dairy Res., Vo. 75, pp. 481-484

Çardak, A. D. (2005). Effects of genetic variants in milk protein on yield and composition of milk from Holstein-Friesian and Simmentaler cows. S. Afr. J. Anim. Sci., Vol. 35, No. 1, pp. 41-47 
Caroli, A. M., Chessa, S. \& Erhardt, G. J. (2009). Invited review: Milk protein polymorphisms in cattle: Effect on animal breeding and human nutrition.J. Dairy Sci., Vol. 92, pp. 5335 5352

Caroli, A., Chessa, S., Bolla, P., Budelli, E. \& Gandini, G. C. (2004). Genetic structure of milk protein polymorphisms and effects on milk production traits in a local dairy cattle. $J$. Anim. Breed. Gen., Vol. 121, No. 2, pp. 119-127

Çelük, Ş. \& Zdemür, S. (2006). $\beta$-Lactoglobulin variants in Awassi and Morkaraman sheep and their association with the composition and rennet clotting time of the milk.Turk. J. Vet. Anim. Sci., Vol. 30, pp. 539-544

Charon, K. \& Świtoński, M. (2000). Genetyka zwierząt. Warszawa. Wydawnictwo Naukowe PWN.

Chen, S. Y., Costa, V., Azevedo, M., Baig, M., Malmakov, N., Luikart, G., Erhardt, G. \& BejaPereira, A. (2008). Short Communication: New Alleles of the Bovine $\kappa$-Casein Gene Revealed by Resequencing and Haplotype Inference Analysis. J. Dairy Sci., Vol. 91, pp. 3682-3686

Chessa, S., Ceriotti, G., Dario, C., Erhardt, G. \& Caroli, A. (2003). Genetic polymorphisms of $\alpha_{\mathrm{s} 1-}, \alpha_{\mathrm{s} 2-}$ and $\kappa$-casein in Maltese goat breed.Ital. J. Anim. Sci., Vol. 2, Suppl. 1, pp. 58-60

Chianesse, L., Garro, G., Mauriello, R., Laezza, P., Ferranti, P. \& Addeo, F. (1996). Occurrence of five $\alpha$ s1-casein variants in ovine milk. J. Dairy Res., Vol. 63, pp. 49-59

Chiatti, F., Chessa, S., Bolla, P., Cigalino, G., Caroli, A. \& Pagnacco, G. (2007). Effect of кcasein polymorphism on milk composition in the Orobica goat. J. Dairy Sci., Vol. 90, No. 4, pp. 1962-1966

Citek, J., Panicke, L., Rehout, V. \& Prochazkova, H. (2006). Study of genetic distances between cattle breeds of Central Europe. Czech J. Anim. Sci., Vol. 51, No. 10, pp. 429-436

Clark, S. \& Sherbon, J. W. (2000). Genetic variants of alpha s1-CN in goat milk: breed distribution and associations with milk composition and coagulation properties. Small Rum. Res., Vol. 38, pp. 135-143

Comin, A., Cassandro, M., Chessa, S., Ojala, M., Dal Zotto, R., De Marchi, M., Carnier, P., Gallo, L., Pagnacco, G. \& Bittante, G. (2008). Effects of composite $\beta$ - and $\kappa$-casein genotypes on milk coagulation, quality, and yield traits in Italian Holstein cows. J. Dairy Sci., Vol. 91, pp. $4022-4027$

Cosenza, G., Pauciullo, A., Coletta, A., Di Francia, A., Feligini, M., Gallo, D., Di Berardino, D. \& Ramunno, L. (2011). Short communication: Translational efficiency of casein transcripts in Mediterranean river buffalo. J. Dairy Sci., Vol. 94, pp. 5691-5694

Creamer, L. K. \& Harris, D. P. (1997). Association between milk protein polymorphism and milk production traits. Proc. IDF Seminar "Milk Protein Polymorphism II" North Palmerston, New Zeland, pp. 22-37

Da Salva, I. T. \& Del Lama, M. A. (1997). Milk protein polymorphisms in Brazilian Zebu cattle. Braz. J. Genet., Vol. 20, No. 4, pp. 625-630

Devold, T. G., Nordbø, R., Langsrud, T., Svenning, C., Jansen Brovold, M., Sørensen, E. S., Christensen, B., Ådnøy, T. \& Vegarud, G. E. (2010). Extreme frequencies of the $\alpha s_{1}-$ casein "null" variant in milk from Norwegian dairy goats - Implications for milk 
composition, micellar size and renneting properties. D. Sci. Tech., DOI: $10.1051 / \mathrm{dst} / 2010033$

Di Luccia, A., Mauriello, R., Chianesse, L., Moio, L. \& Addeo, F. (1990). א-casein polymorphism in caprine milk. Sci. Tech. Latt. Cesearia, Vol. 41, pp. 305-314

Ehrmann, S., Bartenschlager, H. \& Geldermann, H. (1997). Quantification of gene effects on single milk proteins in selected groups of dairy cows. J. Anim. Breed. Genet., Vol. 114, pp. 121-132

El Nahas, S. M., de Hondt, H. A. \& Womack, J. E. (2001). Current status of the River Buffalo (Bubalus bubalis L.) gene map. J. Hered., Vol. 92, No. 3, pp. 221-225

El-Hanafy, A. A., El-Saadani, M. A., Eissa, M., Maharem, G. M. \& Khalifa, Z. A. (2010). Polymorphism of $\beta$-lactoglobulin gene in barki and damascus and their cross bred goats in relation to milk yield. Biotech. Anim. Husb., Vol. 26, No. 1-2, pp. 1-12

Ellegren, H. (2004). Microsatellites: simple sequences with complex evolution. Nat. Rev. Genet., Vol. 5, pp. 435-445

El-Shazly, S. A., Mahfouz, M. E., Al-Otaibi1, S.A. \& Ahmed, M. M. (2012). Genetic polymorphism in $\beta$-lactoglobulin gene of some sheep breeds in the Kingdom of Saudi Arabia (KSA) and its influence on milk composition. Afr. J. Biotechnol., Vol. 11, No. 19, pp. $4330-4337$

Erhardt, G., Juszczak, J., Panicke, L. \& Krick-Saleck, H. (1998). Genetic polymorphism of milk proteins in Polish Red Cattle: a new genetic variant of $\beta$-lactoglobulin. J. Anim. Breed. Genet., Vol. 115, pp. 63-71

Farrell, H. M., Jimenez-Flores, R., Bleck, G. T., Brown, E.M., Butler, J. E. \& Creamer, L. K. (2004). Nomenclature of the proteins of cows' milk - sixth revision. J. Dairy Sci., Vol. 87, pp. 1641-1674

Feleńczak, A., Fertig, A., Gardzina, E. \& Jezowit-Jurek, M. (2004). Technological characteristics of milk obtained from cows of Red-White and Simmental breeds and their relationship with the polymorphism of к-casein (in Polish). Ann. Anim. Sci., Suppl. 19 , pp. $55-58$

Feleńczak, A., Gil, Z., Adamczyk, K., Zapletal, P. \& Frelich, J. (2008). Polymorphism of milk $\kappa$-casein with regard to milk yield and reproductive traits of Simmental cows. J. Agrob., Vol. 25, No. 2, pp. 201-207

FitzGerald, R. J. (1996). Exploitation of casein variants. Cab International "Milk composition, production and biotechnology", Hamilton, New Zealand, pp. 153-172

Giambra, I. J., Chianese, L., Ferranti P. \& Erhardt, G. (2010). Genomics and proteomics of deleted ovine CSN1S1*I. Int. Dairy J., Vol. 20, pp. 195-202

Hallen, E. A., Wedholm, A. A. \& Lunden, A. (2008). Effect of $\beta$-casein, $\kappa$-casein and $\beta$ lactoglobulin gynotypes on concentration of milk protein variants. J. Anim. Breed. Genet., Vol. 17, pp. 791-799

Hanusová, E., Huba, J., Oravcová, M., Polák, P. \& Vrtková, I. (2010). Genetic Variants of Beta-Casein in Holstein Dairy Cattle in Slovakia. Slovak J. Anim. Sci., Vol. 43, No. 2, pp. $63-66$ 
Heck, J. M. L., Schennink, A., van Valenberg, H. J. F., Bovenhuis, H., Visker, M. H. P. W., van Arendonk, J. A. M. \& van Hooijdonk, A. C. M. (2009). Effect of milk protein variants on the protein composition of bovine milk. J. Dairy Sci., Vol. 92, 1192-1202

Heidari, M., Ahani Azari, M., Hasani, S., Khanahmadi, A. \& Zerehdaran, S. (2009). Association of genetic variants of $\beta$-lactoglobulin gene with milk production in a herd and a superior family of Holstein cattle. Iran. J. Biotech., Vol. 7, No. 4, pp. $254-257$

Henderson, D. A. \& Marshall, D. M. (1996). Kappa-casein genotype effects in a multiple breed beef cattle population. J. Anim. Sci., Supp.1, Vol.74, pp. 121

Huang, W., Penagaricano, F., Ahmad, K. R., Lucey J. A., Weigel, K. A. \& Khatib, H. (2012). Association between milk protein gene variants and protein composition traits in dairy cattle. J. Dairy Sci., DOI: 10.3168/jds.2011-4757

Iannuzzi, L., Di Meo, G. P., Perucatti, A., Schibler, L., Incarnato, D., Gallagher, D., Eggen, A., Ferretti, L., Cribiu, E. P. \& Womack, J.(2003). The river buffalo (Bubalus bubalis, $2 \mathrm{n}=50$ ) cytogenetic map: Assignment of 64 loci by fluorescence in situ hybridization and Rbanding. Cytogenet. Genome Res. Vol. 102, pp. 65-75.

Ibeagha-Awemu, E. M., Bemji, M. N., Osinowo, O. A., Chiatti, F., Chessa, S. \& Erhardt, G. (2005). Caprine milk protein polymorphisms: Possible applications for African goat breeding and preliminary data in Red Sokoto. In: The role of biotechnology in animal agriculture to address poverty in Africa: opportunities and challenges. Proceedings of 4th All Africa Conference on Animal Agriculture and the 31 ${ }^{\text {st }}$ Annual Meeting of the Tanzania Society for Animal Production (TSAP), Arusha, Tanzania, 20-24 September, pp. 323-358

Ibeagha-Awemu, E. M., Prinzenberg, E. M., Jann, O. C., Luhken, G., Ibeagha, A. E., Zhao, X. \& Erhardt, G. (2007). Molecular Characterization of Bovine CSN1S2*B and Extensive Distribution of Zebu-Specific Milk Protein Alleles in European Cattle. J. Dairy Sci., Vol. 90, pp. 3522-3529

Ikonen, T., Ojala, M., Ruottinen, O. \& Georges, M. (2001). Association between casein hyplotypes and first lactation milk production traits in Finish Ayrshire cows. J. Dairy Sci., Vol. 84, pp. 507-514

Ilie, D., Sălăjeanu, A., Magdin, A., Stanca, C., Vintilă, C., Vintilă, I. \& Gócza, E. (2007). Genetic polymorphism at the $\kappa$-casein locus in a dairy herd of Romanian Spotted and Brown of Maramures breeds.Lucrări ştiinţifice Zootehnie şi Biotehnologii, Vol. 40, No. 1, pp. 101-106

Imafidon, G. I. \& Ng-Kwai-Hang, K. F. (1991). Effect of genetic polymorphism on the thermal stability of $\beta$-lactoglobulin and א-casein mixture. J. Dairy Sci., Vol. 74, pp. 17911802

Jann, O., Ceriotti, G., Caroli, A. \& Erhardt, G. (2002). A new variant in exon VII of bovine bcasein gene (CSN2) and its distribution among European cattle breeds. J. Anim. Breed. Genet., Vol. 119, pp. 65-68

Jordana, J., Amills, M., Díaz, E., Angulo, C., Serradilla, J. M. \& Sánchez, A. (1996). Gene frequencies of caprine $\alpha$ s1-casein polymorphism in Spanish goat breeds. Small Rum. Res., 20, 215-221 
Jõuru, I., Henno, M., Värv, S., Kaart, T. \& Kärt, O. (2007). Milk protein genotypes and milk coagulation properties of Estonian Native cattle. Agric. Food Sci., Vol. 16, pp. 222-231

Kamiński, S. (2001). Polymorphism of bovine milk proteins. Dissertations and monographs (in Polish). Published by Warmińsko-Mazurski University, Olsztyn.

Karima, K. Gh. M., Nawito, M. F. \& Abdel Dayem, A. M. H. (2010). Sire selection for milk production traits with special emphasis on kappa casein (CSN3) gene. Global J. Molecular Sci., Vol. 5, No. 2, pp. 68-73

Khatkar, M. S., Thomson, P. C., Tammen, I. \& Raadsma, H. W. (2004). Quantitative trait loci mapping in dairy cattle: review and meta-analysis. Genet. Sel. Evol., No. 36, pp. 163-190

Król, J. (2003). The association between genetic variants of milk proteins with milk yield of beef cattle and the results of rearing of their offspring. Part I - Hereford breed (in Polish). Annales UMCS, Sec. EE, Vol. XXI, No. 1, pp. 81-89

Krukovics, S., Daroczi, L., Kovacs, P., Molnar, A., Anton, I., Zsolnai, A., Fesus, L. \& Abraham, M. (1998). The effect of $\beta$-lactoglobulin genotype on cheese yield. EAAP Publ., Vol. 95, pp. 524-527

Krzyżewski, J., Ryniewicz, Z., Strzałkowska, N. \& Bagnicka, E. (2002). The concentration of selected macro- and microelements in goat milk depending on the polymorphic variants of $\alpha$ s1-casein (in Polish). Prace i Mat. Zoot., Vol. 14, pp. 93-101

Krzyżewski, J., Strzałkowska, N., Ryniewicz, Z., Bagnicka, E. \& Oprządek, A. (2000). The relationship between polymorphic variants of alfa-s1-CN and also the daily yield and chemical composition of goat milk during lactation (in Polish). Zesz. Nauk. AR Wroctaw, Vol. 399, pp. 189-198

Kučerova, J., Matějiček, A., Jandurova, O. M., Sorensen, P., Němcova, E., Štipkova, M., Kott, T., Bouška, J. \& Frelich, J. (2006). Milk protein genes CSN1S1, CSN2, CSN3, LGB and their relation to genetic values of milk production parameters in Czech Fleckvieh. Czech J. Anim. Sci., Vol. 51, No. 6, pp. 241-247

Li, Y. C., Korol, A. B., Fatima, T., Beiles, A. \& Nevo, E. (2002). Microsatellite: genomic distribution, putative functions and mutational mechanisms: a review. Molec. Ecol., No. 11, pp. 2453-2465

Li, Y. C., Korol, A. B., Fatima, T. \& Nevo, E. (2004). Microsatellite within genes: structure, function and evolution. Mol. Biol. Evol., No. 21, pp. 991-1007

Litwińczuk, A., Barłowska, J., Król, J. \& Litwińczuk, Z. (2006). Milk protein polymorphism as a marker of functional traits of dairy and beef cattle (in Polish). Vet. Med., Vol. 62, No. 1, pp. 6-10

Litwińczuk, A., Kędzierska-Matysek, M. \& Barłowska, J. (2007). Performance and quality of milk of various genotypes of $\alpha$ s1-casein obtained from goats from the region of Wielkopolska and Podkarpacie (in Polish). Vet. Med., Vol. 63, pp. 192-195

Litwińczuk, A., Kędzierska-Matysek, M., Król, J. \& Barłowska, J. (2004). Productivity of white improved and non-improved goat breeds characterized with different genetic variants of $\alpha$ s1-casein (in Polish). Zesz. Nauk. Przeg. Hod., Vol. 72, No. 3, pp. 133-139

Litwińczuk, Z. \& Król, J. (2002). Polymorphism of main milk proteins in beef cattle maintained in East-Central Poland. Anim. Sci. Pap. Rep., Vol. 20, No. 1, pp. 33-40 
Liu, Z. J. \& Cordes, J. F. (2004). DNA marker technologies and their applications in aquaculture genetics. Aquaculture, No. 238, pp. 1-37

Liu, Z. J., Li, P., Kocabas, A., Ju, Z., Karsi, A., Cao, D. \& Patterson, A. (2001). Microsatellitecontaining genes from the channel catfish brain: evidence of trinucleotide repeat expansion in the coding region of nucleotide excision repair gene RAD23B. Biochem. Biophys. Res.Commun., Vol. 289, pp. 317-324

Lodes, A., Buchberger, J., Krause, I., Aumann, J. \& Klostermeyer, H. (1997). The influence of genetic variants of milk protein on the compositional and technological properties of milk. Content of protein, whey protein and casein number. Milchwissenschaft, Vol. 52, pp. 3-8

Luhken, G., Caroli, A., Ibeagha-Awemu, E. M. \& Erhardt, G. (2009). Characterization and genetic analysis of bovine as1-casein/ variant. Anim. Gen., Vol. 40, pp. 479-485

Lunden, A., Nilsson, M. \& Janson, L. (1997). Marked effect of $\beta$-lactoglobulin polymorphism on the ratio of casein to total protein in milk. J. Dairy Sci., Vol. 80, pp. 2996-3005

Mahé, M. F., Manfredi, E., Ricordeau, G., Piacere, A. \& Grosclaude, F. (1994). Effects of $\alpha$-s1 casein polymorphism on the dairy performances of Alpine goat breed. Genet. Sel. Evol., Vol.26, pp. 151-157

Marini, A. B. A., Rashid, B. A., Musaddin, K. \& Zawawi, I. (2011). as1-Casein gene polymorphism in Katjang, Jamnapari, Boer and Boer-feral goats in Malaysia. J. Trop. Agric. and Fd. Sc., Vol. 39, No. 1, pp. 1-5

Marle-Köster, E. \& Nel, L. H. (2003). Genetic markers and their application in livestock breeding in South Africa: A review. South Afr. J. Anim. Sci., Vol. 33, No. 1, pp. 1-10

Martin, P., Michale, O. B. \& Grosclaude, F. (1999). Genetic polymorphism of caseins: A tool to investigate casein micelle organization. Intern. Dairy J., Vol. 9, pp. 163-171

Matějíček, A., Matějíčková, J., Němcová, E., Jandurová, O.M., Štípková, M., Bouška, J. \& Frelich, J. (2007). Joint effects of CSN3 and LGB genotypes and their relation to breeding values of milk production parameters in Czech Fleckvieh. Czech J. Anim. Sci., Vol. 52, No. 4, pp. 83-87

McLean, D. M., Graham, E. R. B., Ponzoni, R. W. \& McKenzie, H. A. (1984). Effect of milk protein genetic variants on milk yield and composition. J. Dairy Res., Vol. 51, pp. 531546

Mercier, J. C., Grosclaude, F. \& Ribadeau-Dumas, B. (1971). Structure primaire de la caseine $\alpha$ s1 bovine. Sequence complete. Eur. J. Biochem., Vol. 23, pp. 41-51

Moatsou G., Vamvakaki A. N., Mollé D., Anifantakis E. \& LéoniL J. (2006). Protein composition and polymorphism in the milk of Skopelos goats. Lait, Vol. 86, pp. 345-357

Moatsou, G., Moschopoulou, E., Molle, D., Gagnaire, V., Kandarakis, I. \& Leonil, J. (2008). Comparative study of the protein fraction of goat milk from the Indigenous Greek breed and from international breeds, Food Chem., Vol. 106, pp. 509-520

Mohammadi, A., Nassiry, M. R., Elyasi, G. \& Shodja, J. (2006). Genetic polymorphism of $\beta$ lactoglobulin in certain Iranian and Russian sheep breeds. Irani. J. Biotech., Vol. 4, No. 4, pp. 265-268 
Mroczkowski, S., Korman, K., Erhard, G., Piwczyński, D. \& Borys, B. (2004). Sheep milk protein polymorphism and its effect on milk performance of Polish Merino. Arch. Tierz., Vol. 47, pp. 114-121

Mroczkowski, S., Korman, K., Piwczyński, D. \& Erhard, G. (2002). The influence of sheep genotype of $\alpha \mathrm{S} 1$-casein on milk productivity of Polish Merino in the first three lactations (in Polish). Zesz. Nauk. Przeg. Hod., Vol. 63, pp. 139-144

Naqvi, A. N. (2007). Application of Molecular Genetic Technologies in Livestock Production: Potentials for Developing Countries. Adv. Biol. Res., Vol. 1, No. 3-4, pp. 72-84

Ng-Kwai-Hang, K. F. (1997). A review of the relationship between milk protein polymorphism and milk composition/milk production. Proc. IDF Seminar "Milk Protein Polymorphism II" North Palmerston, New Zeland, 22-37

Ng-Kwai-Hang, K. F., Otter, D. E., Lowe, E., Boland, M. J. \& Auldist, M. J. (2002). Influence of genetic variants of $\beta$-lactoglobulin on milk composition and size of casein micelles. Milchwissenschaft, Vol. 57, pp. 303-306

Nilsen, H., Olsen, H. G., Hayes, B., Sehested, E., Svendson, M., Nome, T., Meuvissen, T. \& Lien, S. (2009). Casein hyplotypes and their association with milk production traits in Norwegian Red cattle. Genet. Sel. Evol., Vol. 41, No. 24, pp. 1-12

Nudda, A., Feligini, M., Battacone, G., Campus, R. \& Pulina, G. (2000). Effects of $\beta$ lactoglobulin genotypes and parity on milk production and coagulation properties in Sarda dairy ewes. Zootecnica E Nutrizone Animale, Vol. 26, pp. 137-143

Olenski, K., Kamiński, S., Szyda, J. \& Cieslinska, A. (2010). Polymorphism of the beta-casein gene and its associations with breeding value for production traits of Holstein-Friesian bulls. Livestock Sci., Vol. 131, pp. 137-140

Pierre, A., le Quere, J. L., Famelart, M. H. \& Rousseau, F. (1996). Cheeses from goat milks with or without $\alpha \mathrm{s} 1-\mathrm{CN}$. In: Production and Utilization of Ewe and Goat Milk. Proc. Of the IDF/Greek National Committee of IDF/CIRVAL Seminar, Crete, Greece, pp.322

Pisarchik, A. V. \& Kartel, N. A. (2000). Simple repetitive sequences and gene expression. Mol. Biol., Vol. 34, pp. 303-307

Pop, F. D., Balteanu, V. A. \& Vlaic, A. (2008). A comparative analysis of goat $\alpha$ s1-casein locus at protein and DNA levels in carpathian goat breed. Bulletin UASVM Anim. Sci. Biotech., Vol. 65, No. 1-2, pp. 1843-5262

Ramunno, L., Longobardi, E., Pappalardo, M., Rando, A., Di Gregorio, P., Cosenza, G., Mariani, P., Pastore, N. \& Masina, P. (2001). An allele associated with a non-detectable amount of $\alpha$ s2-casein in goat milk. Anim. Gen., Vol. 32, pp. 19-26

Remeuf, F. (1993). Influence du polymorphisme génétique de la caséine alfa S1 caprine sur les caractéristiques physico-chimiques et technologiques du lait. Lait, Vol. 73, pp. 549557

Ren, D. X., Miao, S. Y., Chen, Y. L., Zou, C. X., Liang, X. W. \& Liu, J. X. (2011). Genotyping of the $\mathrm{k}$-casein and $\beta$-lactoglobulin genes in Chinese Holstein, Jersey and water buffalo by PCR-RFLP. Journal of Genetics, Vol. 90, No. 1, e1-e5.

Rincón, G., Armstrong, E. \& Postiglioni, A. (2006). Analysis of the population structure of Uruguayan Creole cattle as inferred from milk major gene polymorphisms. Genet. Mol. Biol., Vol. 29, No. 3, pp. 491-495 
Robitaille, G., Britten, M. \& Petitclerc, D. (2001). Effect of a differential allelic expression of kappa-casein gene on ethanol stability of bovine milk. J. Dairy Res., Vol. 68, pp. 145-149

Ryniewicz, Z., Krzyżewski, J. \& Jasińska, L. (1998). The relationship between polymorphic variants of goat's CSN1S1 and cow's LGB and the susceptibility of total proteins to enzymatic hydrolysis of milk (in Polish). Prace i Mat. Zoot., Vol. 53, pp. 75-82

Ryniewicz, Z., Reklewska, B., Krzyżewski, J., Strzałkowska, N. \& Gałka, E. (2000). The possibilities of improving the national population of goats and their milk properties and the correlation to recent research results obtained in IGiHZ PAN in Jastrzębiec (in Polish). Annals of Warsaw Agricultural University - SGGW, Anim. Sci., Vol. 37, pp. 2129

Sacchi, P., Chessa, S. \& Budelli, E. (2005). Casein Haplotype Structure in Five Italian Goat Breeds. J. Dairy Sci., Vol. 88, No. 4, pp. 1561- 1568

Schmidely, P., Meschy, F., Tessier, J. \& Sauvant, D. (2002). Lactation response and nitrogen, calcium, and phosphorus utilization of dairy goats differing by the genotype for $\alpha_{\mathrm{s} 1-}$ caseine in milk, and fed diets varying in crude protein concetration. J. Dairy Sci., Vol. 85, pp. $2299-2307$

Shende, T. C., Sawane, M. P. \& Pawar, V.D. (2009). Genotyping of Pandharpuri buffalo for к-casein using PCR-RFLP. Tamilnadu J. Vet. Anim. Sci., Vol. 5, No. 5, pp. 174-178

Stoneking, M. (2001). Single nucleotide polymorphisms: From the evolutionary past. Nature, Vol. 409, pp. 821-822

Strzałkowska, N., Bagnicka, E., Jóżwik, A., Krzyżewski, J. \& Ryniewicz, Z. (2004). Chemical composition and some technological milk parametres of Polish White Improved Goats. Arch. Tierz., Vol. 47, pp. 122-128

Strzelec, E. \& Niżnikowski, R. (2009). Single nucleotide polymorphism (SNP) of selected genes in representatives of the family Bovidae with particular emphasis on domestic goats. Anim. Prod. Rev., No. 7, pp. 7-14

Supakorn, Ch. (2009). The Important Candidate Genes in Goats - A Review. Walailak J. Sci. Tech., Vol. 6, No. 1, pp. 17-36

Sztankóová, Z., Senese, C., Czerneková, V., Dudková, G., Kott, T., Mátlová, V. \& Soldát, J. (2005). Genomic analysis of the CSN2 and CSN3 loci in two Czech goat breeds. Anim. Sci. Pap. Rep., Vol. 1, No. 23, pp. 67-70

Teneva, A. \& Petrović, M. P. (2010). Application of molecular markers in livestock improvement. Biotech. Anim. Husb., Vol. 26, No. 3-4, pp. 135-15

Teneva, A. (2009). Molecular markers in animal genome analysis. Biotech. Anim. Husb., Vol. 25, No. 5-6, pp. 1267-1284

Torres-Vázquez, J. A., Vázquez Flores, F., Montaldo, H. H., Ulloa-Arvizu, R., Posadas, M. V., Vázquez, A. G. \& Morales, R. A. A. (2008). Genetic polymorphism of the $\alpha$ s1-casein locus in five populations of goats from Mexico. Electronic J. Biotech., Vol.1, No.3, pp. 2-11

Tsiaras, A. M., Bargouli, G. G., Banos, G. \& Boscos, C. M. (2005). Effect of kappa-casein and ßeta-lactoglobulin loci on milk production traits and reproductive performance of Holstein cows. J. Dairy Sci., Vol. 88, pp. 327-334

Vassal, L. \& Manfredi, E. (1994). Des lait plus riches. Chevre, No. 201, pp. 33-36 
Vătăşescu-Balcan, R. A., Georgescu, S. E., Manea, M. A., Dinischiotu, A. \& Costache, M. (2007). Analysis of beta-lactoglobulin and kappa-casein genotypes in cattle. Conference paper Archiva Zootechnica, Vol. 10, pp. 103-106

Veress, G., Kusza Sz., Bősze, Z., Kukovics, S. \& Jávor, A. (2004). Polymorphism of the $\alpha$ s1casein, K-casein and B-lactoglobulin genes in the Hungarian Milk Goat. S. Afr. J. Anim. Sci., Vol. 34, Supp. 1, pp. 20-23

Vlaic, A., Balteanu, V. A. \& Carsai, T. C. (2011). Milk Protein Polymorphism Study in Some Romanian Sheep Breeds. Bulletin UASVM Anim. Sci. Biotech., Vol. 68, No. 1-2, pp. 27-31

Walawski, K., Sowiński, G., Czarnik, U. \& Zabolewicz, T. (1994). Beta-laktoglobulin and kappa-casein polymorphism in relation to production traits and technological properties of milk in the herd of Polish Black-and-White cows. Genet. Pol., Vol. 35, No. 1/2, pp. 93-108

Winkelman, A. M. \& Wickham, B. W. (1997). Associations between milk protein genetic variants and production traits in New Zealand dairy cattle. In: Milk protein polymorphism. Proceedings of the IDF Seminar held in Palmerston North, New Zealand. Int Dairy Fed, 38-46.

Yahyaoui, M. H., Pena, R. N., Sanchez, A. \& Folch, J. M. (2000). Rapid communication: Polymorphism in the goat $\beta$-lactoglobulin proximal promoter region1. J. Anim. Sci., Vol. 78, pp. 1100-1101 